\title{
PLANTAS CON ACTIVIDAD ANTI-HELICOBACTER PYLORI: UNA REVISIÓN
}

\author{
ISRAEl CASTILlO-JuÁreZ e IRMA ROMERO \\ Departamento de Bioquímica, Facultad de Medicina, Edificio D, $1^{\circ}$ Piso, \\ Universidad Nacional Autónoma de México, 04510 México, D.F., México. \\ Tel. (52 55) 5623 2511, Fax. (52 55) 56162419. \\ 'Autor para la correspondencia. Correo-e: irma@bq.unam.mx
}

\begin{abstract}
Resumen: La bacteria Helicobacter pylori está reconocida como el principal agente causal de la gastritis crónica activa y de la úlcera péptica. Por muchos años, en la medicina tradicional se han utilizado diversas plantas para tratar estos padecimientos; sin embargo, sólo recientemente se ha empezado a investigar su posible efecto sobre la bacteria. Este trabajo compendia y analiza los estudios de plantas con actividad anti-H. pylori que hasta la fecha se han realizado. Se propone que la forma como pudieran estar actuando estas plantas sobre H. pylori es mediante un efecto atenuante de la población bacteriana y no mediante su erradicación, como lo hacen los antibióticos de la terapia anti-ulcerosa que actualmente se utiliza. Las especies vegetales se presentan como una fuente muy diversa para la obtención de compuestos activos con potencial bactericida, así como para el desarrollo de nuevas terapias diseñadas para el control de H. pylori.
\end{abstract}

Palabras clave: actividad anti-H. pylori, agentes derivados de plantas, gastritis, Helicobacter pylori, úlcera.

\begin{abstract}
The bacterium Helicobacter pylori is recog n i zed as the main causal agent of active ch ronic gastritis and peptic ulcer. For many years, traditional medicine has made use of several plants for the tre atment of these afflictions; nevertheless, their possible effect upon the bacterium has just begun to be investigated. This study summarizes and analyzes the studies, conducted up to date, of plants with anti-H. pylori activity. It is proposed that their action on H. pylori is mainly directed to the depletion of bacterial population rather than to its eradication, as the current anti-ulcer therapy does. Plant species are presented as a very diverse source of bactericidal compounds, as well as for the development of new therapies for H. pylori control.
\end{abstract}

Key words: anti-H. pylori activity, gastritis, Helicobacter pylori, plant derived agents, ulcer.

$\boldsymbol{H}$ elicobacter pylori es una bacteria polimórfica Gram negativa que habita en la superficie del epitelio del estómago humano. En 1994, fue declarada por la OMS como el principal agente causal de la úlcera péptica y la Agencia Internacional de Investigaión sobre Cáncer la clasificó como un carcinógeno grupo 1 (IARC, 1994; NIH, 1994). En 2005, los investigadores Barry J. Marshall y J. Robin Wa rren recibieron el premio Nobel de Fisiología o Medicina "por el descubrimiento de H. pylori y su papel en la ga s tritis y la úlcera péptica" (nobelprize.org).

La gastritis consiste en una serie de procesos inflamatorios e inmunes en la mucosa y submucosa del estómago, mientras que la úlcera es una etapa posterior e implica el rompimiento de la mucosa que sobrepasa la muscu - laris mucosae y se puede presentar tanto en el estómago como en duodeno. Se sabe que la gastritis aguda es producida por diversos factores como son H. pylori, autoinmunidad, re flujo biliar, fármacos y substancias tóxicas, pe ro para el caso de la gastritis crónica activa, la bacteria es la principal causante. Así mismo, es la responsable de $85 \%$ de las úlceras gástricas y de $95 \%$ de las duodenales, y está ligada al desarrollo de cáncer gástrico, el cual ocupa el segundo lugar dentro de la mortalidad por cánceres (Dixon, 1994; IARC, 1994; Kuipers et al., 1995; Valle et al., 1996; Ferlay et al., 2001). Se estima que en los países desamollados, entre 30 y $50 \%$ de las personas están colonizadas por $H$. pylori, fracción que asciende a $80 \%$ de la población en los países en vías de desarrollo 
(Taylor y Parsonnet, 1995). Sin embargo, solamente de 10 a $20 \%$ desarrolla úlceras y de 1 a $2 \%$ cáncer gástrico (Ernst y Gold, 2000).

Pa ra eliminar a la bacteria se utiliza un procedimiento denominado triple terapia, el cual consiste en la combinación de dos antibióticos (que pueden ser amoxicilina, metronidazol, te traciclina o clari tromicina) y un inhibidor de la secreción ácida (Goodwin, 1997; Dehesa et al., 1998). Este tratamiento no es efectivo en alrededor de $20 \%$ de los casos, principalmente por la aparición de cepas resistentes, por lo que se ha propuesto la utilización de una segunda línea de tratamiento (una terapia cuádruple) en la que se añade bismuto y antibióticos dife rentes de los previamente utilizados (Pa rente et al., 2003). El uso de varios agentes en la terapia resulta limitado debido a los efectos secundarios que provocan, lo que sugi e re que el tratamiento contra $H$. pylori necesita ser rediseñado (Gisbert y Pajares, 2002; McLoughlin et al., 2004; Bytzer y O'Morain, 2005; Di Mario et al., 2006; Fo rd et al., 2006).

Aunque está demostrado el papel de la bacteria en las patologías descritas, existen evidencias de que no todas las c epas de H. pylori causan daño y se plantea que antes de iniciar una campaña de erradicación se debe estudiar cuáles serían los beneficios y las consecuencias de hacerlo. Actualmente se recomienda que se haga únicamente en los pacientes que presenten úlcera péptica y/o linfomas gástricos MALT (del inglés mucosa-associated lymphoid tissue) y en algunos casos de gastritis crónica activa (Blaser, 1992, 1997, 1998, 1999a, b).

Antes de reconocer a $H$. pylori como el principal age nte etiológico de la gas tritis y la úlcera péptica, la búsqueda de agentes derivados de plantas (AP) —ex tractos crudos, f racciones y compuestos - para tratar estas enfermedades ya había sido abordado. En estos trabajos se encontra ron mecanismos de acción que involu craban efectos ga s tro p rotectores o inhibidores de la secreción de ácido (Borelli e Izzo, 2000), pero actualmente se ha visto que muchas plantas reportadas etnobotánicamente para este tipo de padecimientos actuán también sobre el principal agente causal, la bacteria $H$. pylori.

La búsqueda de propiedades anti-H. pylori en plantas es reciente. El primer reporte que se tiene es de CasselB e raud et al. (1991), y es a partir de los últimos cinco años que este tipo de estudios ha aumentado considerablemente. El presente artículo compendia y analiza la información de los estudios que se han hecho hasta la fecha sobre plantas con actividad anti-H. pylori en todo el mundo.

\section{Plantas con actividad anti-H pylori}

En el apéndice 1 se enlistan 327 plantas, tanto de uso medicinal como comestible, a las que se les ha analizado su potencial anti-H. pylori. Se encuentran ordenadas por familias, seguidas por el nombre científico y el común; este último se tomó del trabajo original, pero de aquellas plantas que también se distribu yen en México, así como de algunas que no se les reporta, se mencionan con el nombre común que se les da en nuestro país. Las familias, así como algunos nombres científicos, fueron corregidos o comoborados de acuerdo con la base de datos en línea del Ja rdín Botánico de Missouri, W ${ }^{3}$ TROPICOS (consultada du rante 2006). También se señala la actividad anti-H. pylo $r i$, la parte de la planta utilizada, así como el tipo de ex tracto que se probó.

En cuanto a la actividad anti-H.pylori, a $60.8 \%$ de estas especies se les ha identificado algún AP positivo, pe ro a la m ayoría sólo se le ha demostrado con estudios in vitro. Cabe señalar que el criterio para considera rlas activas se basa en lo rep o rtado por los autores que realizaron el análisis. Debido a la gran va riación de las condiciones en las que fueron evaluados, no es posible definir un intervalo de inhibición signific ativo o hacer comparaciones de efectividad entre los distintos trabajos. En la última columna del apéndice 1 se indican los compuestos o grupos de compuestos identificados con actividad anti-H. pylori.

A continuación se reseñan los trabajos de las plantas a la cuales se les ha estudiado su efectividad anti-H. pylori in vivo, así como de aquellas que ayudan a contra rrestar el daño producido por la infección.

\section{B rassica oleraceae (brócoli)}

Se ha investigado la eficacia del retoño fresco de brócoli p a raeliminar a $H$. pylori en pacientes infectados a dosis de 14, 28 y 56 g, suministrado dos veces al día por siete días. $\mathrm{Al}$ medir la respuesta mediante antígenos de suero, biopsias gástricas y por la prueba de la ureasa, se encontró una lige ra mejoría en los pacientes que lo consumieron (Galan et al., 2004). En otro estudio hecho con 438 empleados de una fábrica japonesa, por medio de encuestas y por medición de los pepsinógenos I y II (indicadores de daño y at ro fia de la mucosa gástrica), se observó que no existía una asociación entre el consumo de brócoli y la baja prevalencia de ga stritis crónica atrófica (Sato et al., 2004). En un estudio posterior, se administra ron yog u res que contenían brócoli y brócoli fresco a voluntarios infectados con H. pylori; este tratamiento también resultó inefectivo para la erradicación de la bacteria (Opekun et al., 2005). Sin embargo, el sulforofano (figura 1), compuesto muy abu ndante en el brócoli, es capaz de eliminar a H. pylori en cultivos de líneas de células epiteliales de estómago humano (HEp-2) infectadas con la bacteria (Fahey et al., 2002; Haristoy et al., 2005). Además, resultó efectivo (a una dosis de $1.33 \mathrm{mg} /$ día, administrado vía catéter durante cinco días) para erradicar a la bacteria en ratones desnudos con injertos de tejido gástrico humano (xenó grafos) a los cuales se les infectó con H. pylori (Haristoy et al., 2003). 


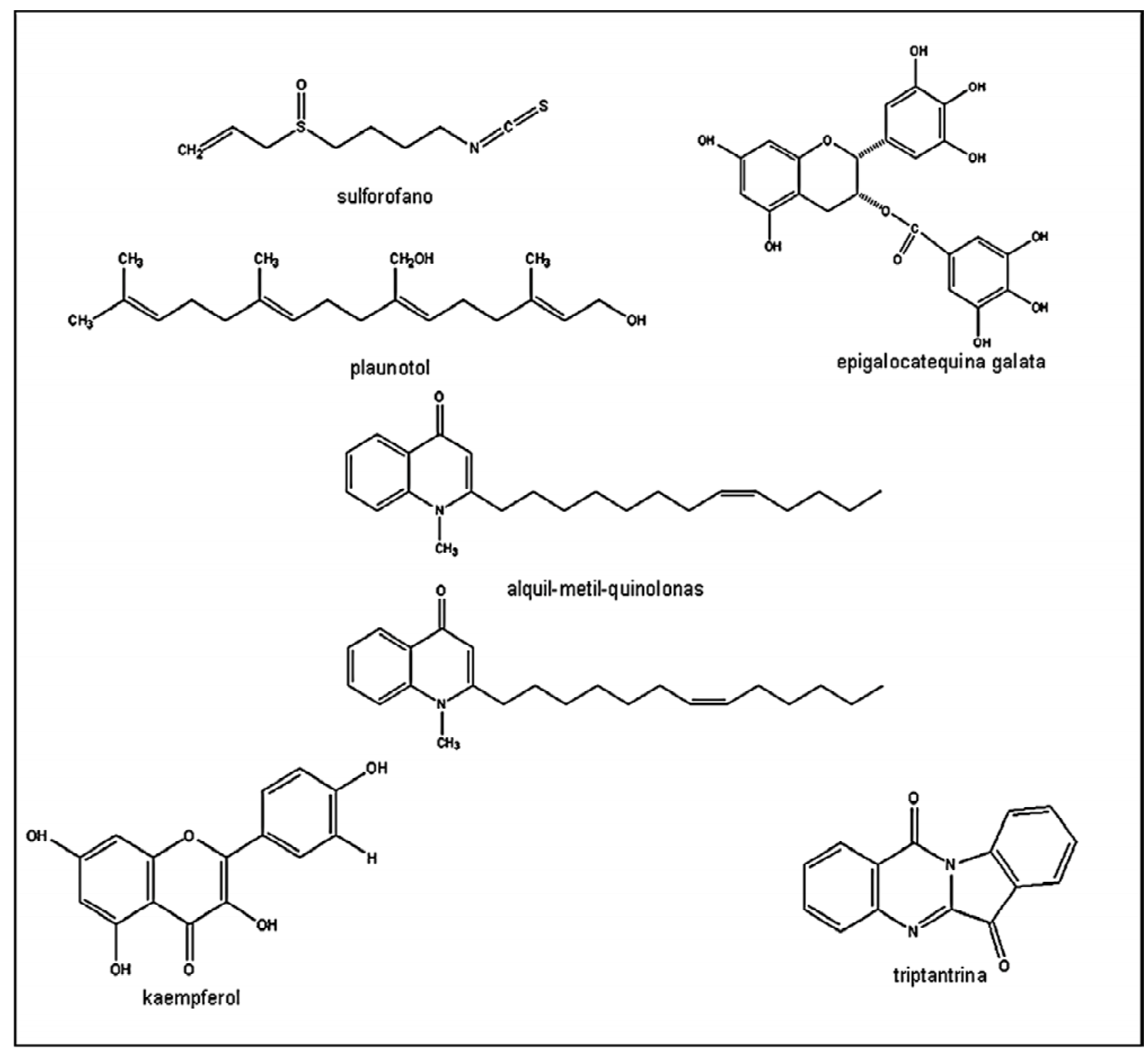

Fig. 1. Principales compuestos con actividad anti-H. pylori aislados de plantas.

\section{Camellia sinensis (té negro, té verde, té de catequinas)}

De las hojas del árbol de Camellia sinensis se elabora el té ve rde (Polyphenon 70s®) y el té negro (Theaflavin $®$ ), cuya dife rencia radica en que el segundo se somete a un p roceso de fermentación. Ambos han mostrado capacidad p a ra inhibir el crecimiento de H. pylori (Mabe et al., 1999; Yee et al., 2002; Matsubara et al., 2003; Takabayashi $e t$ $a l ., 2004)$ y se ha identificado una mezcla de catequinas como la responsable. La eficiencia de estos compuestos está determinada por la presencia de ácido gálico, así como de grupos hidroxilos dentro de su estructura. De la mezcla de catequinas, la epi galoc atequina ga 1 ata (EGCG) (figura 1) es el compuesto mayoritario y el más activo
(Mabe et al., 1999). Se han realizado va rios estudios utilizando gerbos como modelo animal, en los que la mezcla de catequinas disminu ye el número de bacterias y la erradica en 10-36\% de los animales tratados. Entre los posibles mecanismos de acción de estos compuestos se ha demostrado que dañan la membrana, a fectando la morfología de la bacteria y su movilidad, además de inhibir la actividad de la ureasa (Mabe et al., 1999; Matsubara et al., 2003). Contrario a esto, Tombola et al. (2003) no encontraron un efecto sobre la ureasa y proponen, junto con el trabajo de Yahiro et al. (2005), un mecanismo de acción directo sobre la citotoxina vacuolizante (Vac A) de $H$. pylori, tanto del té como de las catequinas. Por otro lado, se ha visto que la EGCG no sólo actúa sobre la bacteria, 
sino que también protege a la mucosa gástrica de la apoptosis y del daño al ADN producidos por H. pylori, estimula la proliferación celular y, al evitar la glucosilación del TLR-4, atenúa la síntesis de mediadores pro-inflamatorios (Lee K.M. et al., 2004).

\section{Croton subly ratus (croton, plaunoi)}

Al terpeno plaunotol, aislado de las hojas de Croton subly ratus (figura 1), se le ha atribuido una acción citoprotectora en la patología de la úlcera, pe rotambién se ha visto que presenta un efecto bacteriolítico sobre H. pylori (Koga et al., 1996). Asimismo, este compuesto inhibe la secreción de interlucina 8 (IL-8) y afecta la adhesión de la bacteria a las células epiteliales gástricas (Takagi et al., 2000). Utilizando ratones como modelo animal, se ha observado que es capaz de disminuir el número de bacterias, efecto que es favo recido si se combina con amoxicilina y claritromicina (Koga et al., 2002).

\section{Evodia rutaecarpa (gosyuyu, wu-chu-yu)}

Del fruto de esta especie se ha aislado una serie de quinolonas tipo alcaloide que inhiben el crecimiento de H.pylo ri (Rho et al., 1999). Su eficacia in vitro es muy similar a la de los antibióticos de re fe rencia utilizados en el estudio y nomue stran toxicidad ni afectan la viabilidad de cultivos de células humanas (Hamasaki et al., 2000). Las quinolonas 1-metil-2-[(Z)-8-tridecenil]-4-(1H)-quinolona y el 1metil-2-[(Z)-7-tridecenil]-4-(1H)-quinolona (fig u ra 1) son c apaces de disminuir el número de bacterias en los estó$\mathrm{m}$ agos de gerbos a dosis de 2, 10 y $20 \mathrm{mg} / \mathrm{kg}$ de peso administrados durante siete días, pe rmitiendo además que exista una disminución en el infiltrado de neutrófilos en la mucosa gástrica. Se observó que la actividad anti-H. pylori aumenta si se combinan con un inhibidor de la secreción gástrica (Tominaga et al., 2002). El mecanismo de acción aún no queda claro, pero se ha encontrado que este tipo de compuestos inhiben la síntesis del ADN bacteriano al actuar sobre la ADN gi rasa y la ADN topoisomerasa IV, además de que son inhibidores competitivos del transporte de electrones en la cadena respiratoria de la bacteria (Rho et al., 1999; Tominaga et al., 2002; Tominaga et al., 2005).

\section{Panax ginseng (ginseng) y otras plantas con propieda- des anti-adhesión}

Se han identificado va rios compuestos con actividad antiH. pylori de la raíz de Panax ginseng, siendo el panaxitriol el más activo (Bae et al., 2001a). También se ha encontrado un grupo de carbohidratos de carácter ácido que muest ran una actividad inhibitoria de la hemoaglutinación de la bacteria (Belogo rt s eva et al., 2000). Fracciones de polisa- cáridos, tanto del ginseg como de Artemisia capillaris, inhiben el pegado de la bacteria a células epiteliales humanas derivadas de adenocarcinoma gástrico (Lee J.H. et al., 2004; Lee et al., 2006). En el caso del ginseg se ha encontrado un efecto protector, ya que es capaz de inhibir la muerte celular apoptótica, reducir el daño al ADN y atenuar la ex presión del gen de la IL8 (Pa rk et al., 2005). Por otra part e, se han identificado polisacáridos ácidos de las semillas de Ribes nigrum y del jugo de Abelmoschus escu lentus (quingombó) que inhiben la adhesión en secciones de mucosa gástrica humana al bloquear los receptores de superficie de la bacteria (Lengsfeld et al., 2004a, b).

Los extractos acuosos de las hojas de Arctostaphylos uva-ursi y Vaccinium vitis-ideae presentan una actividad bacteriostática, la cual se atribu ye a la gran cantidad de taninos que contienen y que además son capaces de modificar la hidro fobicidad de la superficie, aumentando la agregación celular (Annuk et al., 1999). Por otro lado, algunos constituyentes de elevado peso molecular del jugo del fruto de Vaccinium macrocarpon inhiben la adhesión específica al ácido siálico, el cual es importante para las adhesinas de la bacteria (Burger et al., 2000; Burger et al., 2002; Shmuely et al., 2004). El ex tracto acuoso de $V$. macrocarpon también presenta un efecto anti-H. pylori asociado a la presencia de compuestos fenólicos, que se ve favo recido por la combinación con Ori ga num vulga re (Lin et al., 2005). En un estudio con pacientes $H$. pylori positivos se encontró un efecto positivo de $V$. macrocarpon en la eliminación de la bacteria a una dosis de $500 \mathrm{ml}$ de jugddía administrado oralmente durante 90 días y determinado por la pru eba de la ureasa (Zhang et al., 2005).

\section{Poly go num tinctorium (índigo japonés)}

Un conjunto de compuestos aislados de la planta presentan actividad anti-H. pylori in vitro (Hashimoto et al., 1999), de los cuales el flavonoide kaempfe rol y el alcaloide tri ptantrina (figura 1) son capaces de disminuir el número de bacterias en estómagos de gerbos a una dosis de $5 \mathrm{mg} / \mathrm{kg}$ de peso, administrados durante 10 días. La triptantrina es más efectiva que el kaempferol, pero el efecto se aumenta si se administran conjuntamente. Sin embargo, el tratamiento con amoxicilina, claritromicina y metronidazol utilizado como control positivo resulta ser más efectivo que el de los tratamientos experimentales, aunque cabe señalar que en ninguno de los dos casos se logró erradicar a la bacteria por completo (Kataoka et al., 2001).

\section{Mezclas herbales y ext ractos de diversas plantas}

El kampo hochu-ekki-to es ampliamente utilizado en Japón y es una mezcla de ex tractos acuosos calentados de distintas plantas ("raíz de Astragali, Ginseng, Angelicae, Bupleuri y Gly cy rrhizae; ri zoma de Atractylodis lanceae, 
Cimicifugae y Gingiberis; fruto de Zizyphi y peri c a rpo de Auranti nobilis", composición reportada en Yan et al., 2002). Esta mezcla inhibe el crecimiento de diferentes c epas de H. pylori, algunas de ellas resistentes a antibióticos comerciales (Imamu ra et al., 1995; Hizuka et al., 1997; Kijima et al., 1999; Yan et al., 2002). Así mismo, disminuye el número de bacterias en ratones C57BL/6 infectados, a dosis de $1,000 \mathrm{mg} / \mathrm{kg} /$ día de ex tracto por 21 días (7 días antes de la inoculación y 14 posteriores), pero sólo se logra erradicar si se combina con otros antibióticos (Yan et al., 2002).

El extracto acuoso de arroz sometido a un proceso de s a carinización y fe rmentación muestra un efecto bacteriostático sobre $H$. pylori. En un modelo animal con gerbos in fectados con la bacteria, se encontró que la administración ad libitum de este ex tracto durante 10 días causa una ligera reducción en el número de bacterias, además de reducir la inflamación y la proliferación epitelial de la mucosa gástrica (Murakami et al., 2005).

El concentrado de jugo de albaricoque japonés Prunus mume (ume) reduce signific at ivamente el número de bacte rias en un modelo de infección con gerbos, a dosis de 1 y 3\% de jugo en agua de beber durante 10 semanas, así como también disminu ye la inflamación y el daño a la mucosa (hiperplasias) (Otsuka et al., 2005). Del fruto se ha aislado e identificado el compuesto (+)-Siri n ga resinol, el cual inhibe la movilidad de H. pylo ri in vitro (Miyazawa et al., 2006).

La actividad anti-H. pylori de ex tractos y compuestos de Allium sativum (ajo) in vitro, es de las más reportadas (Cellini et al., 1996; Sivam et al., 1997; Chung et al., 1998; Jo n ke rs et al., 1999; Ohta et al., 1999; Yoshida et al., 1999; Mahady y Pendland, 2000; O’Gara et al., 2000; Mahady et al., 2001; Sivam, 2001; Cañizares et al., 2002; S ovova et al., 2002; Ohno et al., 2003; Adeniyi y Anyiam, 2004; Cañizares et al., 2004a, b) y sólo en algunos casos se han obtenido resultados negativos (Tabak et al., 1996; O'Mahony et al., 2005). Sin embargo, en los pocos estudios in vivo que se han hecho no se ha encontrado que a fecte la viabilidad de la bacteria.

In troduciendo en la dieta de pacientes $H$. pylori positivos rebanadas de ajo y midiendo la infección por la pru eba de la ureasa no se observó algún efecto en la disminución de la infección (Graham et al., 1999). Tampoco se observa ron resultados positivos con el tratamiento de una cápsula de $4 \mathrm{mg}$ de aceite de ajo, administrada cuat ro veces al día durante 14 días (McNulty et al., 2001). Estos resultados se obtienen nuevamente utilizando un modelo de infección en gerbos, los cuales recibieron una dosis de ex tracto de ajo al $4 \%$ durante seis semanas, aunque en este caso sí se observa una reducción, d ependiente de la dosis, de las hemorragias y de la gas tritis en los grupos tratados (Iimu ro et al., 2002).

La actividad anti-H. pylori de extractos in vitro de la corteza de Cinnamomum cassia (canela china) es muy eficiente; incluso éstos inhiben en el espectro de los antibióticos de referencia (ampicilina, tetraciclina y eritromicina). De esta planta se han aislado e identificado 57 constit u yentes químicos, de los cuales 10 se han probado contra la bacteria, resultando el cinamaldehído el más activo (Tabak et al., 1999). Contra rio a estos resultados, se observó que el ex tracto alcohólico de $C$. cassia, administrado a pacientes infectados con $H$. pylori a una dosis de 80 $\mathrm{mg}$ /día por cuatro semanas, es incapaz de erradicar a la bacteria (Nir et al., 2000).

Finalmente, el ex tracto metanólico de Lafoensia pacari (man gava-brava), administrado a una dosis de $500 \mathrm{mg}$ por 14 días a 55 pacientes $H$. pylori positivos, dio resultados negat ivos (determinado mediante la pru eba de rompimiento de urea) en la erradicación de la bacteria (da Mota Menezes et al., 2006).

\section{Comentarios finales}

Antes del descubrimiento de $H$. pylori como el principal agente etiológico de la gas tritis crónica y la úlcera péptica, se creía que estas patologías se debían únicamente a un desequilibrio entre los factores defensivos y los agresivos de la mucosa gástrica, causado básicamente por el exceso de acidez, el estrés, la ingesta de algunos productos como el alcohol, los irritantes y algunos medicamentos. Los estudios de plantas con potencial anti-ulceroso eran realizados en modelos de ulceración producidos por métodos químicos y físicos (ligado del píloro, estrés, administración de fármacos antinflamatorios no esteroidales, ácido dorhídrico, alcohol, etc.) (Robert et al., 1979) y las actividades que se reportaban tenían que ver con efectos ga stro protectores e inhibidores de la secreción de ácido (Borrelli e Izzo, 2000).

Marshall y Wa rren (1984) propusi eron que la ga s tritis y la úlcera péptica eran producidas principalmente por $H$. pylori. Sin embargo, hace apenas algunos años que se comenzó a buscar AP con una acción directa sobre ella (Mahady, 2005). Por otro lado, es también reciente el desarrollo de modelos animales, en los cuales la gastritis y la úlcera se producen por la infección de la bacteria (Sawa da et al., 1998; Wata nabe et al., 1998; Ikeno et al., 1999).

Se han descrito ya va rios AP que afectan la viabilidad de $H$. pylori, aunque aún no hay estudios orientados a conocer el mecanismo exacto por el cual lo hacen. El pri ncipal inconveniente sobre estos trabajos es que la mayoría sólo han sido realizados in vitro y las condiciones que se han utilizado presentan una gran va riación (tamaño del inóculo, c epa bacteriana, tiempo de incubación, falta de uso de antibióticos de referencia, entre otras), lo que dificulta la realización de un análisis comparat ivo de la efectividad o la definición de un intervalo de inhibición significativo. Con el objetivo de estandarizar las condiciones 
para el cálculo de la actividad mínima inhibitoria de compuestos sobre H. pylori in vitro, se han propuesto dos métodos, uno por el Comité Nacional para la Estandarzación Clínica de Laboratorio y el otro por el Grupo Europeo de Estudio de H. pylori (Glupczynski et al., 1998). Cabe señalar que sólo en algunos trabajos de AP con actividad anti-H. pylori se han tomado en cuenta di chas recomendaciones (Yee y Koo, 2000; Hari s toy et al., 2003; Mahady et al., 2005; Nostro et al., 2005; De Marino et al., 2006; Nostro et al., 2006).

Se pueden clasificar los mecanismos por los cuales los AP pudieran aliviar las patologías producidas por $H$. pylo $r i$ en varios niveles, pe ro hay que estar conscientes de que aún faltan más estudios y que muchos de ellos han mostrado que hay sinergismos que favo recen su actividad.

1. Preventivo. En esta cat egoría tendríamos plantas que se consumen frecuentemente en la dieta, como algunos frutos y especias. Aunque aún no está muy cla rosu papel, el brócoli, el ajo y el chile, al igual que algunos cítricos, podrían incluirse en este grupo (López-Carrillo y FemándezOrtega, 1995; Zhang et al., 1997; Yee et al., 2002; Bergo n zelli et al., 2003; López-Carrillo et al., 2003; Li et al., 2005; O’Mahony et al., 2005; Nakagawa et al., 2006). Un factor indispensable para la colonización de la bacteri a es el pegado a las células epiteliales del estómago, por lo que teniendo en cuenta los estudios realizados en A. capi llaris, $P$. ginseng (Lee J.H. et al., 2004; Lee et al., 2006), R. nigrum, A. esculentus (Lengsfeld et al., 2004a, b) y V. macrocarpon (Burger et al., 2000; Burger et al., 2002; Shmuely et al., 2004), estas plantas podrían estar previniendo la infección de esta manera.

2. Atenuante. Probablemente este sea el principal mecanismo de acción de las plantas usadas tradicionalmente y que actúan sobre $H$. pylori, en el que se disminuye su número o retrasa su crecimiento. Este efecto se ha encontrado pri ncipalmente a nivel de extractos o mezclas herbales, como es el caso de las hojas de A. uva-ursi y V. vitis-idea (Annuk et al., 1999), del kampo (Imamu ra et al., 1995; Hizuka et al., 1997; Kijima et al., 1999; Yan et al., 2002), del arroz (Murakami et al., 2005) y de P. mume (Otsuka et al., 2005; Miyazawa et al., 2006).

3. Protector. Muchos ex tractos y compuestos son capaces de at e nuar el daño causado por la infección al disminuir la inflamación y el daño a la mucosa. Se ha reportado que disminuyen el infiltrado de polimorfos nucleares, atenúan la expresión o la secreción de interlucina 8, reducen el daño al ADN, inhiben la muerte celular apoptótica y favorecen la proliferación epitelial. Algunas de estas actividades o varias de ellas son exhibidas por la epigalocatequina gal ata aislada de C. sinensis (Lee K.M. et al., 2004), el ex tracto de arroz (Murakami et al., 2005), el jugo de $P$. mume (Otsuka et al., 2005), el P. ginseg (Pa rk et al., 2005), el plaunotol aislado de $C$. subly rat us (Tak agi et al., 2000) y algunas quinolonas de E. rutaecarpa (Tominaga et al., 2002).

4. Eliminador. Se han encontrado dive rsos AP que pres entan esta actividad en estudios in vitro, pero hasta la fecha, para ninguno de ellos se ha demostrado que elimine completamente a la bacteria in vivo. No obstante, los compuestos puros tienen un gran potencial para ser incluidos en la te rapia en combinación con otros AP o antibióticos comerciales (Kawase y Motohashi, 2004).

Por otra parte, no toda la va riedad de cepas de $H$. pylo $r i$ son patógenas, ya que el daño se presenta únicamente bajo ciertas circunstancias y asociado a determinados genotipos bacterianos (Blaser, 2005). Recientemente se ha analizado el efecto de la eliminación de $H$. pylori a nivel mundial y se ha encontrado una correlación directa entre la disminución de la bacteria y el aumento en la incidencia del re flujo gastroesofágico, del síndrome de Barret y del cáncer de esófago. Esto ha llevado a pensar que la bacteri a puede resultar benéfica para el humano, ya que su presencia, aparentemente, evita la aparición de estas enfermedades gástricas superi o res (Blaser, 1992, 1997, 1998, 1999a, b, 2005; Akhter et al., 2007).

Pa ra explicar esta situación se ha suge rido que existe un equilibrio entre las diversas poblaciones de $H$. pylori y el humano que favo rece una relación simbiótica, pero que el uso desmedido de antibióticos y la disminución de su incidencia en los niños (que son el principal amplificador de la bacteria en las poblaciones humanas) han provocado la selección de cepas y un decremento de la dive rsidad genética de las poblaciones de H. pylori, conduciendo a la relación patógena. Aparentemente, el desequilibrio entre $H$. pylori y el humano se ha hecho más evidente en las últimas décadas y ha ocasionado un aumento en la incidencia de la ga s tritis y de la úlcera péptica (considerada como una "enfermedad de la civilización" o de la era moderna) y el cáncer gástrico (Blaser, 1998). Sin embargo, el uso de plantas para tratar estos padecimientos es mucho más antiguo. ¿Cuál podría ser entonces el efecto de estas plantas sobre H. pylori?

La necesidad de utilizar terapias tan agresivas para eliminar a la bacteria indica su enorme adaptación para permanecer en el estómago y nos habla de lo difícil que sería lograr erradicarla usando un único AP. Si se compara la eficiencia de los AP con algunos antibióticos de referencia utilizados en los estudios, sólo algunos compuestos puro s p resentan una eficiencia similar in vitro. Además, no se ha demostrado que erradique a la bacteria in vivo y sólo se ve aumentado su efecto si se utilizan va rios de ellos o se combinan con otros antibióticos (Jon ke rs et al., 1999; Mabe et al., 1999; Koga et al., 2002; Tominaga et al., 2002; Yan et al., 2002; Takabayashi et al., 2004; Nostro et al., 2006). 
Estos datos parecen indicar que los tratamientos tradicionales con plantas no han actuado, ni actúan, e rradicando a la bacteria como se busca con las terapias que actualmente se utilizan. Es posible que antes del aumento en la incidencia de la úlcera y del cáncer gástrico, las plantas hayan tenido un papel fundamental en el mantenimiento del equilibrio H. pylori-humano, evitando el desarrollo de estas enfermedades.

Los estudios de plantas con posible actividad anti- $H$. pylori se han hecho con la idea de encontrar una total erradicación de la bacteria por parte de los AP, pero como se mencionó anteri ormente, sólo es recomendable hacerlo en una pequeña parte de las personas colonizadas. Por tal razón, lejos de ver una desventaja en el efecto atenuante del crecimiento de $H$. pylori por parte de los AP hasta ahorareportados, su sinergismo con los efectos preventivo y gastroprotector, son una buena opción para el desarrollo de una terapia reguladoradel equilibrio $H$. pylori-humano.

Como conclusión, se puede afi rmar que para muchas especies vegetales reportadas etnobotánicamente en varias regiones del mundo para tratar la gastritis y las úlceras se ha encontrado que afectan la viabilidad de la bacteria $H$. pylori. La mayor parte de esta actividad ha sido analizada únicamente in vitro, procedimiento que requiere de una estandarżación y de su corroboración con estudios in vivo. $\mathrm{Mu}$ chos AP pueden actuar a dife rentes niveles y favorecer la cura de la enfe rmedad por medio de efectos sinérgicos. Las plantas son una fuente muy diversa para la obtención de compuestos químicos con potencial bactericida, que pueden ser incluidos en las terapias de emadicación, ex clusivamente en aquellos casos de patologías muy avanzadas (úlcera péptica y cáncer gástrico) y en los que es necesario eliminarh. Proponemos que el modo de acción de las plantas utilizadas tradicionalmente para padecimientos re lacionados con la ga s t ritis y la úlcera péptica, ha sido y es a través del control de la población de la bacteria y no eliminándola por completo, como se pretende con las terapias actuales.

\section{A gradecimientos}

A Edelmira Linares Mazari por la revisión de los nombre s co munes de las plantas del apéndice 1. A Martha Alicia Lydia Macías Rubalcava y a los revisores anónimos por sus comentarios al manuscrito. A CONACyT por el ap oyo 53043 del Fondo de Formación de Doctores. Israel Castillo es becario de CONACyT con No. Registro 203169.

\section{Lit erat u racitada}

Adeniyi B.A. y A nyiam F.M. 2004. In vivo anti-Helicobacter pylori potential of methanol extract of Allium ascalonicum Linn. (Liliaceae) leaf: susceptibility and effect on urease acti- vity. Phytothe rapy Research 18:358-361.

An nuk H., Hirmo S., Turi E., Mi kelsaar M., Arak E. y Wadstrom T. 1999. Effect on cell surface hydrophobicity and susceptibility of Helicobacter pylori to medicinal plant ex t racts. FEMS Microbiology Letters 172:41-45.

Akhter Y., Ahmed I., Devi S.M. y Ahmed N. 2007. The co-evo lved Helicobacter pylori and ga s t ric cancer: trinity of bacterial vinulence, host susceptibility and lifestyle. Infectious Agents and Cancer 2:1-5.

Bae E.A., Han M.J., Kim N.J. y Kim D.H. 1998. AntiHelicobacter pylori activity of herbal medicines. Biological \& Pharmaceutical Bulletin 21:990-992.

Bae E.A., Han M.J. y Kim D.H. 1999. In vitro anti-Helicobacter pylori activity of some flavonoids and their metabolites. Planta Medica 65:442-443.

Bae E.A., Han M.J., Baek N. y Kim D.H. 2001a. In vitro antiHelicobacter pylori activity of panaxytriol isolated from ginseng. Archives of Pharmaceutical Research 24:297-299.

Bae E.A., Han M.J. y Kim D.H. 2001b. In vitro anti-Helicobacter pylori activity of irisolidone isolated from the flowers and rhizomes of Pueraria thunbergiana. Planta Medica 67:161-163.

Basile A., Senatore F., Gargano R., Sorbo S., Del Pezzo M., Lavitola A., Ritieni A., Bruno M., S p atuzzi D., Rigano D. y Vuotto M.L. 2006. Antibacterial and antioxidant activities in Sideritis italica (Miller) Greuter et Burdet essential oils. Journal of Ethnopharm a c ology 107:240-248.

Beil W., B i rkholz C. y Sewing K. 1995. Effects of fl avonoids on parietal cell acid secretion, gastric mucosal prostaglandin production and Helicobacter pylori growth. Arzneimittelforschung 45:697-700.

Belogortseva NI., Yoon J.Y. y Kim K.H. 2000. Inhibition of Helicobacter py lo ri hemagglutination by polysaccharide fractions from roots of Panax ginseng. Planta Medica 66:217220.

Bergonzelli GE., Donnicola D., Porta N. y Corthesy-Theulaz I.E. 2003. Essential oils as components of a diet-based ap p roach to management of Helicobacter in fection. Antimicrobial and Agents Chemotherapy 47:3240-3246.

Bhamarapravati S., Pendland S.L. y Mahady G. B. 2003. Extracts of spice and food plants from Thai traditional medicine inhibit the growth of the human carcin ogen Helicobacter pylori. In Vivo 17:541-544.

Blaser M.J. 1992. Hypotheses on the pathogenesis and natural history of Helicobacter pylori-induced inflammation. Gastroentero logy 102:720-727.

Blaser M.J. 1997. Not all Helicobacter pylori strains are created equal: should all be eliminated? Lancet 349.1020-1022.

Blaser M.J. 1998. Helicobacters are indigenous to the human stomach: duodenal ulceration is due to ch an ges in gastric microecology in the modern era. Gut 43:721-727.

Blaser M.J. 1999a. Hypothesis: the changing relationships of Helicobacter pylori and humans: implications for health and disease. The Journal of Infectious Diseases 179.1523-1530.

Blaser M.J. 1999b. In a world of bl ack and white, Helicobacter pylori is gray. Annals of Internal Medicine 130:695-697.

Blaser M.J. 2005. Global warming and the human stomach: microecology follows macroecology. Transactions of the American Clinical and Climat ological Association 116:65-76.

B orrelli F. e Izzo A.A. 2000. The plant kingdom as a source of anti-ulcer remedies. Phytothe rapy Research 14:581-591. 
Burger O., O fek I., Tabak M., Weiss E., Sharon N. y Neeman I. 2000. A high molecular mass constituent of cranberry juice inhibits Helicobacter pylori adhesion to human ga st ric mucus. FEMS Immu no logy and Medical Microbiology 29:295-301.

Burger O., Weiss E., Sharon N., Tabak M., Neeman I. y Ofek I. 2002. Inhibition of Helicobacter pylori adhesion to human ga s tric mucus by a high-molecular- weight constituent of cra nberry juice. Critical Reviews in Food Science and Nutrition 42:279-284.

Bytze P. y O'Morain C. 2005. Treatment of Helicobacter pylo ri. Helicobacter 10:40-46.

Cañizares P., Gracia I., Gómez L., Martín de A rgila C. 2002. Optimization of Allium sativum solvent extraction for the inhibition of in vitro growth of Helicobacter pylori. Biotechnology Progress 18:1227-1232.

Cañizares P., Gracia I., Gómez L., Martín de A rgila C., Boixeda D. y García A. 2004a. The rmal degradation of allicin in ga rlic extracts and its implication on the inhibition of the in-vitro growth of Helicobacter pylori. Biotechnology Progress 20:3237.

Cañizares P., Gracia I., Gómez L., Martín de A rgila C., Boixeda D. y García A. 2004b. Allyl-thiosulfinates, the bacteriostatic compounds of garlic against Helicobacter pylori. Biotechnology Progress 20:397-401.

Cassel-Beraud A.M., Le Jan J., Mouden J.C., Andriantsoa M. y Andriantsiferama R. 1991. Preliminary study of the prevalence of Helicobacter pylori in Tananarive, Madagascar and the antibacterial activity in vitro of 13 Malagasy medicinal plants on this germ. Archives de l'Institut Pasteur de Madaga scar 59:9-23.

Cellini L., Di Campli E., Masulli M., Di Bartolomeo S. y Allocati N. 1996. Inhibition of Helicobacter pylori by ga rlic extract (Allium sativum). FEMS Immunology and Medical Microbiology 13:273-277.

Chatterjee A., Yasmin T., B ag chi D. y Stohs S. 2004. Inhibition of Helicobacter pylori in vitro by various berry extracts, with enhanced susceptibility to clarithromycin. Molecular and Cellular Biochemistry 265:19-26.

Chung J.G., Chen G. W., Wu L.T., Chang H.L., Lin J.G., Yeh C.C. y Wang T.F. 1998. Effects of ga rlic compounds diallyl sulfide and diallyl disulfide on arylamine $\mathrm{N}$-acetyltransfe rase activity in strains of Helicobacter pylori from peptic ulcer patients. The A me rican Journal of Chinese Medicine 26:353-364.

Chung J.G., Hsia T.C, Kuo H.M., Li Y.C., Lee Y.M., Lin S.S. y Hung C.F. 2001. Inhibitory actions of luteolin on the growth and arylamine $\mathrm{N}$-acetyltransferase activity in strains of Helicobacter pylori f rom ulcer patients. Toxicology in Vitro 15:191-198.

Da Mota Menezes V., Atallah A.N., Lapa A.J. y Cat apani W.R. 2006. Assessing the therapeutic use of Lafoensia pacari St. Hil. extract (mangava-brava) in the eradication of Helicobacter pylori: double-blind randomized clinical trial. Helicobacter 11:188-195.

De Leo M., De Tommasi N., S a nogo R., De Angelo V., Germano M.P., Bisignano G. y Braca A. 2006. Trite rpenoid saponins from Pteleopsis suberosa stem bark. Phytochemistry 67:26232629.

De Marino, S., Borbone N., Gala F., Zollo F., Fico G., Pagiotti R. y Iorizzi M. 2006. New constituents of sweet Capsicum anпиит L. fruits and evaluation of their biological activity. Journal of Agricultural and Food Chemistry 54:7508-7516.

Dehesa M., Larisch J., Dibildox M., Vega B., Di Silvio M., R o d riguez L., Camorl in gaM., Al maguer I., Ramirez-Barba E. y Torres J. 1998. Comparison of 2 schedules based on pantopra zole for eradication of Helicobacter pylo ri in patients with active duodenal ulcer. Revista de Gastroenterología de México 63:66-71.

De Pasquale R., Germano M.P., Keita A., Sanogo R. e Iauk L. 1995. Antiulcer activity of Pteleopsis suberosa. Journal of Ethnopharmacology 47:55-58.

Di Mario F., Cavallaro L.G. y Scarpignato C. 2006. Rescue therapies for the management of Helicobacter pylori infection. Dige st ive Disease 24:113-130.

Dixon M.F. 1994. Pathophysiology of Helicobacter pylori infection. Scandinaian Journal of Gastroenterology 201:7-10.

Epifano F., Menghini L., Pagiotti R., An gelini P., Genovese S. y $\mathrm{C}$ urini M. 2006. In vitro inhibitory activity of boropinic acid against Helicobacter pylori. Bioorganic and Medical ChemestryLetters 16:5523-5525.

Ernst P.B. y Gold B.D. 2000. The disease spectrum of Helicobacter pylori: the immunopath ogenesis of gastroduodenal ulcer and gastric cancer. Annual Review of Microbiology 54:615-640.

Fabry W., O kemo P. y An sorg R. 1996a. Activity of east A frican medicinal plants against Helicobacter pylori. Chemotherapy 42:315-317.

Fabry W., O kemo P., M watha W.E., Chhabra S.C. y Ansorg R. 1996b. Susceptibility of Helicobacter pylori and Candida spp. to the east African plant Terminalia spinosa. Arzneimittelforschung 46:539-540.

Fahey J.W., Haristoy X., Dolan P.M., Kensler T.W., S choltus I., Stephenson K., Talalay P. y Loziniewski A. 2002. Sulforaphane inhibits extracellular, intracellular, and antibiotic-resistant strains of Helicobacter pylori and prevents benzo[a]pyrene-induced stomach tumors. Proceedings of the National Academy of Sciences of the United States of America 99.7610-7615.

Ferlay J., B ray F., Pisani P. y Pa rkin D.M. 2001. GLOBOCAN 2000: cancer incidence, mortality and prevalence worldwide, Version 1.0. IARC Cancer Base No. 5. IARC Press, Lyon.

Ford A.C., Delaney B.C., Forman D. y Moay yedi P. 2006. Eradication therapy for peptic ulcer disease in Helicobacter pylori positive patients. Coch rane database of systematic reviews (Online) (2): Art. No.: CD003840. DOI: 10.1002/14651858.CD003840.pub4.

Fukai T., Marumo A., Kaitou K., Kanda T., Te rada S. y Nomu ra T. 2002. Anti-Helicobacter pylori flavonoids from licorice extract. Life Sciences 71:1449-1463.

Funat ogawa K., H ayashi S., Shimomura H., Yoshida T., Hatano T., Ito H. y Hiray Y. 2004. Antibacterial activity of hydrolyzable tannins derived from medicinal plants against Helicobacter pylori. Microbiology and Immunology 48:251261.

Gadhi C.A., Benhamef A., Jana M. y Lozniewski A. 2001. AntiHelicobacter pylori activity of Aristolocha paucinervis Pomel ex tracts. Jo u rnal of Ethnopharm a c o logy 75:203-205.

Galan M.V., Kishan A.A. y Silverman A.L. 2004. Oral broccoli sprouts for the treatment of Helicobacter pylori infection: a 
preliminaryreport. Digestive Diseases and Sciences 49:10881090.

Ge rmano M.P., Sanogo R., Guglielmo M., De Pasquale R., Crisafi G. y Bisignano G. 1998. Effects of Pteleopsis subero $s a$ extracts on experimental gastric ulcers and Helicobacter pylori growth. Jo u rnal of Ethnopharmacology 59:167-172.

Gisbert J.P. y Pajares J.M. 2002. Review article: Helicobacter pylori in fection and gastric outlet obstruction - prevalence of the infection and role of antimicrobial treatment. Alimentary Pharmacology \& Therapeutics 16:1203-1208.

Glupczynski Y., Andersen L., López-Brea M. y Mégraud F. 1998. Towards standardisation of antimicrobial susceptibility of $H$. pylori: preliminary results by a European Multicentre Study G roup. Gut 43:A47.

Goel R.K., Sairam K., B abu D., Tavares I.A. y Raman A. 2003. In vitro evaluation of Bacopa monniera on anti-Helicobacter pylori activity and accumulation of prostaglandins. Phytomedicine 10.523-527.

Goel R.K., S a iram K. y Raho C.V. 2001. Role of gastric antiox idant and anti-Helicobacter pylori activities in antiulcerogenic activity of plantain banana (Musa sapientum var. paradisia ca). Indian Journal of Experimental Biology 39:719-722.

Goodwin C.S. 1997. Antimicrobial treatment of Helicobacter pylori in fection. Clinical Infectious Disease 25:1023-1026.

G raham D. Y., Anderson S. Y. y Lang T. 1999. Garlic or jalapeño peppers for treatment of Helicobacter pylori infection. American Jo u rnal of Gastroenterology 94: 1200-1202.

Hamasaki N., Ishii E., Tominaga K., Tezuka Y., Nagaoka T., Kadota S., Kuroki T. y Yano I. 2000. Highly selective antibacterial activity of novel alkyl quinolone alkaloids from a Chinese herbal medicine, Gosyuyu (wu-chu-yu), against Helicobacter pylori in vitro. Microbiology and Immunology 44:9-15.

Haristoy X., Angioi-Duprez K., Duprez A. y Lozniewski A. 2003. Efficacy of sulforaphane in eradicating Helicobacter pylori in human gastric xe nografts implanted in nude mice. Antimicrobial A gents and Chemotherapy 47:3982-3984.

Haristoy X., Fahey J.W., S choltus I. y Lozniewski A. 2005. Evaluation of the antimicrobial effects of several isothiocya$\mathrm{n}$ ates on Helicobacter pylori. Planta Medica 71:326-330.

Hashimoto T., A ga H., Chaen H., Fukuda S. y Ku rimoto M. 1999. Isolation and identific ation of anti-Helicobacter pylori compounds from Polygo num tinctorium Lour. Natural Medicines 53:27-31.

Hizuka H., Hi gasa J. y Yamamoto I. 1997. Antibacterial effect of Kampo medicine against Helicobacterpylo ri. Journal of New Remedies and Clinics 46:49-53.

IARC [Intern ational A gen cy for Research on Cancer]. 1994. Live flukes and Helicobacter pylori. IARC Working group on the evaluation of Carc in ogenic Risks to Human, Lyon, 7-14 June 1994. IARC Monographs on the Evaluation of Carcinogenic Risks to Humans 61:1-241.

Ib rahim M., Khan A.A., Tiwari S.K., Habeeb M.A., Khaja M.N. y Hab i bullah C.M. 2006. Antimicrobial activity of Sapindus mukorossi and Rheum emodi extracts against H. pylori: In vitro and in vivo studies. Wo rld Jo u rnal of Gastroenterology 28:7136-7142.

Iimuro M., Shibata H., Kawa moriT., Matsumoto T., A rakawa T., Sugimur T. y Wakabayashi K. 2002. Suppressive effects of garlic extract on Helicobacter pylori-induced gastritis in Mongolian gerbils. Cancer Letters 187:61-68.

I keno T., Ota H., S u gi yama A., Ishida K., Kat su yama A., Genta R.M. y Kawasaki S. 1999. Helicobacter pylori-induced ch ronic active gastritis, intestinal metaplasia, and gastric ulcer in Mongolian gerbils. The American Journal of Pathology 154:951-960.

Imai, H., Osawa K., Yasuda H., Hamashima H., A rai T. y Sasatsu M. 2001. Inhibition by the essential oils of peppermint and spearmint of the growth of pathogenic bacteria. Microbios 106:31-9.

Imamura L., Tsuchiya M., Inada A., Nakanishi T. y Kobashi K. 1995. Inhibition of urease and growth of Helicobacter pylori by herb extracts. Journal of Traditional Medicines 12:129136.

Isobe T., Doe M., Morimoto Y., N agata K. y Ohsakai A. 2006. The anti-Helicobacter pylori $\mathrm{fl}$ avones in a Brazilian plant, Hyptis fasciculata, and the activity of methoxyflavones. Biological \& Pharmaceutical Bulletin 29.1039-1041.

Isobe T., Ohsaki A. y Nagata K. 2002. Antibacterial constituents against Helicobacter pylori of Brazilian medicinal plant, Pari p a roba. Yakugaku Zasshi 122:291-294.

Jones NL., Shabib S. y Sherman P.M. 1997. Capsaicin as an inhibitor of the growth of the gastric pathogen Helicobacter pylori. FEMS Microbiology Letters 146:223-227.

Jonke rs D., Van den Broek E., Van Dooren I., Thijs C., Dorant E., H ageman G. y Stobberingh E. 1999. Antibacterial effect of garlic and omeprazole on Helicobacter pylori. Journal of Antimicrobial Chemotherapy 43:837-839.

Kalpoutzakis E., Aligiannis N., Mentis A., Mitaku S. y Charvala C. 2001. Composition of the essential oil of two Nepeta species and in vitro evaluation of their activity against Helicobacter pylori. Planta Medica 67:880-883.

Kadota S., Basnet P., Ishii E., Tamura T. y Namba T. 1997. Antibacterial activity of trich o rabdal A from $R$ abdosia tricho carpa against Helicobacter pylori. Zentralblatt fur Bakteriologie 286:63-67.

K ataoka M., Hi rata K., Kunikata T., Ushio S., Iwaki K., Ohashi K., I keda M. y Kurimoto M. 2001. Antibacterial action of tryptanthrin and kaempferol, is olated from the indigo plant (Polygo num tinctorium Lour.), against Helicobacter pyloriinfected Mongolian gerbils. Journal of Gastroenterology 36:5-9.

Kawase M. y Motohashi N. 2004. Plant-derived leading compounds for eradication of Helicobacter pylori. Current Medicinal Chemistry - Anti-Infective Agents 3:89-100.

Kawase M., Motohashi N., S atoh K., Sakagami H., Nakashima H., Tani S., Shirataki Y., Ku ri ha raT., Spengler G., WolfardK. y Molnar J. 2003. Biological activity of persimmon (Diospyros kaki) peel extracts. Phytotherapy Research 17:495-500.

Kijima H., Kajita S. , Saito T., Isobe Y., Fukushima K., Kaneta K., Fujikawa T. y Akashi T.1999. Effect of Anchu-san and Shakuyaku-Kanzoto extract on Helicobacter pylori-induced gastric muscosal inflammation and delayed ulcer healing in Mongolian Gerbils. Japanese Pharmacology \& Therapeutics 27:1493-1499.

Kim D.H., Bae E.A. y Han M.J. 1999. Anti-Helicobacter pylori activity of the metabolites of poncirin from Poncirus trifolia - 
ta by human intestinal bacteria. Biological \& Pharmaceutical Bulletin 22:422-424.

Koga T., Kawada H., Utsui Y., Domon H., Ishii C. y Yashuda H. 1996. Bactericidal effect of plaunotol, a cytoprotective antiulcer agent, against Helicobacter pylori. Journal of Antimicrobial Chemotherapy 38:387-397.

Koga T., Inoue H., Ishii C., Okasaki Y., Domont H. y Utsui Y. 2002. Effect of plaunotol in combination with clarithromycin or amoxicillin on Helicobacter pylori in vitro and in vivo. Journal and Antimicrobial Chemotherapy 50:133-136.

Konstantinopoulou M., Karioti A., Skaltas S. y Skaltsa H. 2003. Sesquiterpene lactones from Anthemis altissima and their anti-Helicobacter pylori activity. Journal of Nat u ral Products 66:699-702.

K rausse R., Bielenberg J., B las chek W. y Ullmann U. 2004. In vitro anti-Helicobacter pylori activity of Extractum liquiri tiae, glycyrrhizin and its metabolites. Journal of Antimicrobiology Chemotherapy 54:243-246.

Kubo J., Lee J.R. y Kubo I. 1999. Anti-Helicobacter pylori agents from the cashew apple. Journal of Agriculturd and Food Chemistry 47:533-537.

Kuipers E.J., Thijs J.C. y Festen H.P.N. 1995. The prevalence of Helicobacter pylori in peptic ulcer disease. Alimentary Pharmacology \& Therapeutics 9.59-69.

Lee J.H., Pa rk E.K., Uhm C.S., Chung M.S. y Kim K.H. 2004. Inhibition of Helicobacter pylori adhesion to human gastric adenocarcinoma epithelial cells by acidic polysaccharides f rom A rtemisia capillaris and Panax ginseng. Planta Medica 70.615-619.

Lee J.H., Shim J. S., Lee J.S., Kim M.K., Chung M.S. y Kim K.H. 2006. Pectin-like acidic polysaccharide from Panax ginseng with selective antiadhesive activity against pat hogenic bacteria. Carbohyd rate Research 341:1154-1163.

Lee K.M., Yeo M., Choue J.S., Jin J.H., Pa rk S.J., Cheong J.Y., Lee K.J., Kim J.H. y Hahm K.B. 2004. Protective mechanism of epigallocatechin-3-gallate against Helicobacter pyloriinduced gastric epithelial cytotoxicity via the blockage of TLR-4 signaling. Helicobacter 9.632-642.

Leng s feldC., DetersA., Faller G. y Hensel A. 2004a. High molecular weight polysacchandes from black currant seeds inhibit adhesion of Helicobacter pylori to human gastric mucosa. Planta Medica 70.620-626.

Lengsfeld C., Titgemeyer F., Faller G. y Hensel A. 2004b. Glycosylated compounds from okra inhibit adhesion of Helicobacter pylori to human gastric mucosa. Journal of Agricultural and Food Chemistry 5 2:1495-1503.

Li Y., Xu C., Zhang Q., Liu J.Y. y Tan R. X. 2005. In vitro antiHelicobacter pylori action of 30 Chinese herbal medicines used to treat ulcer diseases. Journal of Ethnopharm a cology 98:329-333.

Lin Y.T., K won Y., Labbe R. y Shetty K. 2005. Inhibition of Helicobacter pylori and associated urease by oregano and cranberry phy tochemical synergies. Applied Environmental Microbiology 71:8558-8564.

Lopez-Camillo L., Femández-Ort ega M.C., Costa-Dias R., Franco-Marina J. y Alejandre-Badillo T. 1995. Beliefs about chili pepper consumption and health in Mexico City. Salud Pública de México 37:339-343.

López-Carrillo L., López-Cenantes M., Robles-Díaz G.,
Ramírez-Espítia A., Mohar-Betancourt A., Meneses-García A., López-Vidal Y. y A a ron-Bleir A. 2003. Capsaicin consumption, Helicobacter pylori positivity and ga s tric cancer in M exico. International Journal of Cancer 106:277-282.

Mabe K., Yamada M., Oguni I. y Takahashi T. 1999. In vitro and in vivo activities of tea cat e chins against Helicobacter pylori. Antimicrobial A gents Chemotherapy 43:1788-1791.

Mahady G.B. 2005. Medicinal plants for the prevention and treatment of bacterial infections. Current Pharmaceutical Desing 11:2405-2427.

Ma ha dy G. B. y Pendland S. 2000. Garlic and Helicobacter pylori. American Jo u rnal of Gastroenterology 95:309.

Mahady G.B., Matsuura H., Pendlant S. y Pharm D. 2001. Allixin, a phytoalexin from garlic, inhibits the growth of Helicobacter pylori in vitro. American Journal of Gastroentero logy 96:3454-3455.

Mahady G. B., Pendland S.L., Yung G. y Lu Z.Z. 2002. Turmeric (Curcuma longa) and curcumin inhibit the growth of Helicobacter pylori, a group 1 carcinogen. Anticancer Research 22:4179-4181.

Mahady G.B., Pendland S.L., Stoia A. y Chadwi ck L.R. 2003a. In vitro susceptibility of Helicobacter pylori to isoquinoline alkaloids from Sanguinaria canadensis and Hydrastis cana densis. Phy to the rapy Research 17:217-221.

Mahady G.B., Pendland S.L., Yung G.S., Lu Z.Z. y Stoia A. 2003b. Ginger (Zingiber officinale Roscoe) and the gingerols inhibit the growth of Cag A+ strains of Helicobacter pylori. Anticancer Research 23:3699-3702.

Mahady G. B., Pendland S.L., Stoia A., Hamill F.A., Fab ricant D., Dietz B. y Chatwick LR. 2005. In vitro susceptibility of Helicobacter pylo ri to botanical extracts used traditionally for the treatment of gastrointestinal disorders. Phytotheray Research 19:988-991.

Malekzadeh F., Ehsanifar H., Shamamat M., Levin M. y Colwell R.R. 2001. Antibacterial activity of black myrobalan (Terminalia chebula Retz) against Helicobacter pylori. Inte mational Jo u rnal of Antimicrobial Agents 18:85-88.

M a rone P., Bono L., Leone E., Bona S., Carreto E. y Pe rve rsi L. 2001. Bactericidal activity of Pistacia lentiscus mastic gum against Helicobacter pylori. Journal of Chemotheraphy 13:611-614.

Matsubara S., Shibata H., Ishikawa F., Yokokura T., Takahashi M., Sugimura T. y Wakab ayashi K. 2003. Suppression of Helicobacter pylori-induced gastritis by green tea ex tract in Mongolian gerbils. Biochemical and Biophysical Research Communications 310:715-719.

May B., Funk P. y Schneider B. 2003. Pep permint oil and caraway oil in functional dyspepsia-efficacy unaffected by $H$. pylori. Alimentary Pharmacology \& Therapeutics 17:975976.

McLoughlin R., Racz I., Buckley M., Humphrey J. y O’Morain C. 2004. Therapy of Helicobacter pylori. Helicobacter 9:4248.

McNulty C.A., Wilson M.P., Havinga W., Johnston B., O’Gara E.A. y Maslin D. J. 2001. A pilot study to determine the effe ctiveness of ga rlic oil capsules in the treatment of dyspeptic patients with Helicobacter pylori. Helicobacter 6:249-253.

Miyazawa M., Utsunomiya H., Inada K., Yamada T., Okuno Y., Tanaka H. y Tatemats M. 2006. Inhibition of Helicobacter 
pylori motility by (+)-Syringaresinol from unripe Japanese ap ricot. Biological \& Pharmaceutical Bulletin 29:172-173.

Motohashi N., Wakabayashi H., Kurihara T., Takada Y., M a ru yama S., Sakagami H., Nakashima H., Tani S., Shirataki Y., Kawase M., Wolfard K. y Molnár J. 2003. Cytotoxic and multidrug resistance reversal activity of a vegetable, 'Anastasia Red', a variety of sweet pepper. Phytotheraphy Research 17:348-352.

Motohashi N., Wakabayashi H., Kurihara T., Fukushima H., Yamada T., Kawase M., Sohara Y., Tani S., Shirataki Y., Sakagami H., S atoh K., Nakashima H., Molnar A., Spengler G., G yemant N., U gocsai K. y Molnar J. 2004. Biological activity of barbados cherry (acerola fruits, f ruit of Malpighia emarginata DC) extracts and fractions. Phytotheraphy Research 18:212-213.

Mu rakami M., Ota H., Sugiyama A., Ishizone S., Maruta F., Akita N., Okimura Y., Kumagai T., Jo M. y Toku yama T. 2005. Suppressive effect of rice ex tract on Helicobacter pylo $r i$ infection in a Mongolian gerbil model. Journal of Gastroenterology 40:459-466.

Nakagawa H., Takaishi Y., Tanaka N., Tsuchiya K., Shibata H. y Higuti T. 2006. Chemical constituents from the peels of Citrus sudachi. Journal of Nat u ral Products 69.1177-1179.

Nakanishi T., Iida N. , In atomi Y., Mu rata H., Inada A., Mu rata J., Lang F.A., I i numa M., Tanaka T. y Sakagami Y. 2005. A monoterpene glucoside and three megastigmane glycosides from Juniperus communis var. dep ressa. Biological \& Pharmaceutical Bulletin 53:783-787.

Narima F., Eftekhar F., Habibi Z. y Falsasi T. 2004. AntiHelicobacter pylori activities of six Iranian plants. Helicobacter 9:146-151.

NIH. 1994. Consensus Confe rence. Helicobacter py lo ri in pep tic ulcer disease. NIH Consensus Development Panel on Helicobacter py lo ri in peptic ulcer disease. The Jo u rnal of the American Medical Association 272:65-69

Nir Y., Potasman I., Stermer E., Tabak M. y Neeman I. 2000. Controlled trial of the effect of cinnamon extract on Helicobacter pylori. Helicobacter 5:94-97.

Nostro A., Cellini L., Di Bartolomeo S., Cannatelli M.A., Di Campli E., Procopio F., Grande R., Marcio L. y Alonzo V. 2006. Effects of combining extracts (from propolis or Zingiber officinale) with clarithromycin on Helicobacter pylori. Phy tothe rapy Research 20:187-190.

Nostro A., Cellini L., Di Bartolomeo S., Di Campli E., Grande R., Cannatelli M.A., Marzio L. y Alonzo V. 2005. Antibacterial effect of plant extracts against Helicobacter pylori. Phy to the rapy Research 19:198-202.

O'Gara E.A., Hill D. J. y Maslin D. J. 2000. Activities of garlic oil, garlic powder, and their diallyl constituents against Helicobacter pylori. Applied and Environmental Microbiology 66:2269-2273.

O'Mahony R., Al-Khtheen H., Weerasekera D., Fernando N., Vaira D., Holton J. y Basset C. 2005. Bactericidal and antiadhesive properties of culinary and medicinal plants against Helicobacter pylori. World Journal of Gastroenterology 11:7499-7507.

O chi T., Shibata H., Higuti T., Kodama K., Kusumi T. y Takaishi Y. 2005. Anti-Helicobacter pylori compounds from Santalum album. Journal of Natu ral Products 68:819-824.
Ohno T., Kita M., Yamaoka Y., Imamura S., Yamamoto T., Mitsufuji S., Kodama T., Kahima K. y Imanishi J. 2003. Antimicrobial activity of essential oils against Helicobacter pylori. Helicobacter 8:207-215.

Ohsaki A., Takashima J., Chiba N. y Kawamura M. 1999. Microanalysis of a selective potent anti-Helicobacter pylori compound in a Brazilian medicinal plant, Myroxylon peru ife rum and the activity of analogues. Bioorganic and Medicinal ChemistryLetters 9.1109-1112.

Ohta R., Yamada N., KanekoH., Ishikawa K., Fukuda H., Fujino T. y Suzuki A. 1999. In vitro inhibition of the growth of Helicobacter pylori by oil-macerated garlic constituents. Antimicrobial A gents and Chemotherapy 43:1811-1812.

Opekun A.R., Yeh C.W., Opekun J.L. y Graham D.Y 2005. In $v$ ivo tests of nat u ral therapy, Tibetan yog u rt or fresh broccoli, for Helicobacter pylori infection. Methods \& Findings in Experimental \& Clinical Pharmacology 27:327-329.

Ortiz T.H., Mendoza C.R., Cadenas P.E. y Orlando A.J. 2003. Actividad antibacteriana de la sangre de grado (Croton lech leri) frente a Helicobacter pylori. Revista Medica Herediana 14:81-88.

Otsuka T., Tsukamoto T., Tanaka H., Inada K., Utsunomiya H., Mi zoshita T., Ku m agai T., Katsuyama T., Miki K. y Tatematsu M. 2005. Suppressive effects of fruit-juice concentrate of Prunus mume Sieb. et Zucc. (Japanese apricot, Ume) on Helicobacter pylori-induced glandular stomach lesions in Mongolian gerbils. Asian Pacific Journal of Cancer Prevention 6:337-341.

Parente F., Cucino C. y Porro B. G. 2003. Treatment options for patients with Helicobacter pylori in fection resistant to one or more eradication attempts. Digestive and Liver Disease 35:523-528.

Park J-B., Lee C-K. y Park H. 1997. Anti-Helicobacter pylori effect of costunolide isolated from the stem bark of Magnolian sieboldii. Archives of Pharmacal Research 20: 275-279.

Park S., Yeo M., Jin J., Lee K.M., Jumg J., Choue R., Cho S y Hahm K. 2005. Rescue of Helicobacter pylori-induced cy totoxicity by red ginseng. Digestive Diseases and Sciences 50.1218-1227.

Park B-S., Lee H-K., Lee S-E., Piao X-L., Takeoka GR., Wong R.Y., Ahn Y.J. y Kim J-H. 2006. Antibacterial activity of Tabebuia impetiginosa Martius ex DC (Taheebo) against Helicobcater pylo ri. Jo u rnal of Ethnopharm a c ol ogy 105:255262.

Prabjone R., Thong-Ngam D., Wisedopodas N., Chatsuwan T. y Patumraj S. 2006. Anti-inflammatory effects of Aloe ve ra on leukocyte-endothelium interaction in the gastric microcirculation of Helicobacter pylori-infected rats. Clinical Hemorheology and Microcirculation 35:359-366.

Preuss H.G., Echard B., Enig M., B rook I. y Elliott T. B. 2005. Minimum inhibitory concentrations of herbal essential oils and monolaurin for gram-positive and gram-negative bacteria. Molecular and Cellular Bioche mistry 272:29-34.

Rho T.C., Bae E.A., Kim D., Oh W., Kim B. y Lee H. 1999. AntiHelicobacter pylori activity of quinolone alkaloids from Evodiae fructus. Biological \& Pharmaceutical Bulletin 22:1141-1143.

Robert A., Nezamis J.E., Lancaster C., Han char A.J., Robert A. y 
Nezamis J.E. 1979. Cytoprotection by prostaglandins in rats. Prevention of gastric necrosis produced by alcohol, $\mathrm{HCl}$, $\mathrm{NaOH}$, hypertonic $\mathrm{NaCl}$, and thermal injury. Gastroentero logy 77:433-443.

S ato K., K awakami N., Ohtsu T., Tsutsumi A., Mi yasaki S., Masumoto T., Horie S., Haratani T., Ko b ayashi F. y A raki S. 2004. Broccoli consumption and chronic atrophic gastritis among Japanese males: an epidemiological investigation. Acta Medica Okayama 58:127-133.

Sawada Y., Kuroda Y., Sashio H., Yamamoto N., Tonokatsu Y., Sakagami T., Fukuda Y., Shimoyama, T., Nishigami T. y Uematsu K. 1998. Pathological ch an ges in glandular stomach of Helicobacter pylori-infected Mongolian gerbil model. Journal of Gastroenterology 33:22-25.

Shin I.S., Masuda H. y Naohide K. 2004. Bactericidal activity of wasabi (Wasabia japonica) against Helicobacter pylori. Intermational Jo u rnal of Food Microbiology 94:255-261.

Shmuely H., Burger O., Neeman I., Yah av J., Samra Z., Niv Y., Sharon N., Weiss E., Athamna A., Tabak M. y Ofek I. 2004. Susceptibility of Helicobacter pylori is olates to the antiadhesion activity of a high-molecular-weight constituent of cra nberry. Diagnostic Microbiology and Infectious Disease 50.231-235.

Sivam G.P. 2001. Protection against Helicobacter pylori and other bacterial infections by garlic. The Journal of Nutrition 131:1106S-1108S.

Sivam G.P., Lampe J.W. Ulness B., S wanzy S.R. y Potter J.D. 1997. Helicobacter pylori-in vitro susceptibility to garlic (Allium sat iv um) ex tract. Nutrition and Cancer 27: 118-121.

Sovova M., Sova P. y Mra zova A. 2002. Pharmaceutical importance of Allium sativum L. 3. Antibacterial effects on Helicobacter pylori. Ceska a Slovenska Famacie 51:168172.

Stamatis G., Kyri a zopoulos P., Golegou S., Basayiannis A., Skaltsas S. y Skaltsas H. 2003. In vitro anti-Helicobacter pylori activity of Greek herbal medicines. Journal of Ethnophamacology 88:175-179.

St ege P.W., Davicino R.C., Vega A.E., Casali Y.A., Correa S. y Micalizzi B. 2006. Antimic robial activity of aqueous extracts of Larrea divaricata Cav. (jarilla) against Helicobacter pylo ri. Phytomedicine 13: 724-727.

Tabak M., Armon R., Potasman I. y Neeman I. 1996. In vitro inhibition of Helicobacter pylori by extracts of thyme. Journal of Applied Bacteriology 80:667-672.

Tabak M., A rmon R. y Neeman I. 1999. Cinnamon extracts' inhibitory effect on Helicobacter pylori. Journal of Ethnophamacology 67:269-277.

Tak ab ayashi F., Harada N., Yamada M., Mu rohisa B. y Oguni I. 2004. Inhibitory effect of green tea cat e chins in combination with sucral fate on Helicobacter pylori infection in Mongolia n gerbils. Journal of Gastroenterology 39.61-63.

Tak agi A., Koga Y., Aiba Y., K abir A.M., Wat a nabeS., Ohta-Tada U., Osaki T., Kamiya S. y Miwa T. 2000. Plaunotol suppre sses interleukin-8 secretion induced by Helicobacter pylori: th e rapeutic effect of plaunotol on $H$. pylori in fection. Joumal of Gastroentero logy and Hepatology 15:374-380.

Takashima J., Chiba N., Yoneda K. y Ohsaki A. 2002. Derrisin, a new rotenoid from Derris malaccensis plain and antiHelicobacter pylori activity of its related constituents.
Journal of Natural Products 65:611-613.

Taylor D.N. y Parsonnet J. 1995. Epidemiology and nat u ral history of $H$. pylori in fections of the gastrointestinal tract. En: Blaser M.J., Smith P.F., Ravdin J., Greenberg H. y Guerrant R.L. Eds. Infections of the Gastrointestinal Tract, pp. 551564, Raven Press, Nueva York .

Tezuka Y., Zhao W., Ishii E. y Kadota S. (1999). AntiHelicobacter pylori activity of steroidal alkaloids obtained f rom three Ve ratrum plants. Jo u rnal of Traditional Medicines 16: 196-200.

Tombola F., Campello S. Da Luca L., Ruggi e ro P., Del Giudice G., Papini E. y Zoratti M. 2003. Plant polyphenols inhibit VacA, a toxin secreted by the gastric pat hogen Helicobacter pylori. FEBS Letters 543:184-189.

Tominaga K., Higuchi K., Hamasaki N., Hamaguchi M., Takashima T., Tanigawa T., Wat a n abe T., FujiwaraY., Tezuka Y., Nahaoka T., Kadota S., Ishii E., Kob ayashi K. y A rak awa T. 2002. In vivo action of novel alkyl methyl quinolone alkaloids against Helicobacter pylori. Journal of Antimicrobial Chemotherapy 50.547-552.

Tominaga K., Higuchi K., Hamasaki N., Tanigawa T., Sasaki E., Watanabe T., FugiwuaraY., Oshitani N., Arakawa T., Ishii E., Tezuka Y., Nagaoka., T. y Kadota S. 2005. Antibacterial activity of a Chinese herbal medicine, Gosyuyu (Wu-Chu-Yu), against Helicobacter pylori. Nippon Rinsho 63:592-599.

Tran C.D., Butler R.N. y Miller M.J. 2006. The role of A mazonian herbal medicine Sangre de Grado in Helicobacter pylori infection and its association with metallothionein expression. Helicobacter 11:134-135.

Tzakou O. y Skaltsa H. 2003. Composition and antibacterial activity of the essential oil of Saturejaparnassica subsp. par nassica. Planta Medica 69:282-284.

Ustun O., Ozcelik B., A kyon Y., Abbasoglu U. y Yesilada E. 2006. Flavonoids with anti-Helicobacter pylori activity from Cistus laurifolius leaves. Jo u rnal of Ethnopharmacology 108:457-461.

Valle J., Kekki M., Sipponen P., Ihamaki T. y Siurala M. 1996. Long-term course and consequences of Helicobacter pylori gas tritis. Results of a 32-year foll ow-up study. Scandinavian Journal of Gastroenterology 31:546-550.

$\mathrm{W}^{3}$ Tropicos. Missouri Botanical Garden's VAST nomencl at u ral $\mathrm{d}$ at abase and associated authority files. <mobot.mobot.org/W3T/Search/vast.html>

Wang Y.C. y Huang T.L. 2005a. A n t i-Helicobacter pylori activity of Plumbago zeylanica L. FEMS Immu nology and Medical Microbiology 43:407-412.

Wang Y.C. y Huang T.L. 2005b. Screening of anti-Helicobacter pylori herbs deriving from Taiwanese folk medicinal plants. FEMS Immu no logy and Medical Microbiology 43:295-300.

Wat a nabe T., Tada M. Nagai H., Sasaki S. y Masafumi N. 1998. Helicobacter pylori in fection induces gastric cancer in mongolian gerbils. Gastroentero logy 115:642-648.

Yahiro K., Shirasaka D., Tagashira M., Wada A., Morinaga N., Ku roda F., Choi O., Inoue M., A oyama N., Ikeda M., Hirayama T., Moss J. y Noda M. 2005. Inhibitory effects of polyphenols on gastric injury by Helicobacter pylori VacA toxin. Helicobacter 10:231-239.

Yan X., Kita M., Minami M., Yamamoto T., Ku ri yama H., Ohno T., Iwakura Y. y Imanishi J. 2002. Antibacterial effect of 
Kampo herbal formulation Hochu-ekki-to (Bu-Zhong-Yi-QiTang) on Helicobacter pylori infection in mice. Microbiology and Immunology 46:475-482.

Yee Y.K. y Koo M.W. (2000). Anti-Helicobacter pylori activity of Chinese tea: in vitro study. Alimentary Pharma cology \& Therapeutics 14:635-638.

Yee Y.K., Koo M.W. y Szeto M.L. 2002. Chinese tea consumption and lower risk of Helicobacter in fection. Journal of Gastroenterology and Hepatology 17:552-555.

Yesilada E., Gurbuz I. y Shibata H. 1999. Screening of Turkish anti-ulcerogenic folk remedies for anti-Helicobacter pylori activity. Jo u rnal of Ethnopharmacology 66:289-293.

Yoshida H., Katsuzaki H., Ohta R., Ishikawa K., Fukuda H., Fujino T. y Suzuki A. 1999. Antimicrobial activity of the thio- sulfinates isolated from oil-macerated garlic extract. Bioscience Biotechnology \& Biochemistry 63:591-594.

Yoshida T., Hatano T. y Ito H. 2000. Chemistry and function of vegetable polyphenols with high molecular weights. Biofactors 13: 121-125.

Zhang H.M., Wakisaka N., Maeda O. y Yamamoto T. 1997. Vitamin $\mathrm{C}$ inhibits the growth of a bacterial risk factor for gastric carcinoma: Helicobacter pylori. Cancer 80.1897-903.

Zhang L., Ma J., Pan K., Go V.L., Chen J. y You W.C. 2005. Efficacy of cranberry juice on Helicobacterpylo ri infection: a double-blind, randomized placebo-controlled trial. Helicobacter 10:139-145.

Recibido: 10 de enero de 2007

Versión corregida: 25 de abril de 2007

Aceptado: 27 de abril de 2007 
ISRAel CASTILlo-JuÁreZ E Irma RoMERo

Apéndice 1. Plantas con estudios de actividad anti-Helicobacter pylori. Simbología: $\boldsymbol{\Delta}=$ Con actividad anti- $H$. pylori; $\bullet=$ Inhiben adhesión; $>$ = Sin actividad anti-H. pylori; ( ) = solvente utilizado para la extracción; $\bullet=$ Reporte de estudio con actividad gastroprotectora y/o anti-ulceroso; — Información no disponible.

\begin{tabular}{|c|c|c|c|}
\hline $\begin{array}{l}\text { Familia y nombre } \\
\text { científico }\end{array}$ & Nombre común & Parte probada & $\begin{array}{l}\text { Grupos químicos } \\
\text { identificados }\end{array}$ \\
\hline \multicolumn{4}{|l|}{ Aizoaceae } \\
\hline Mollugo cerviana & Anisillo & A Semilla (agua); O'Mahony et al. (2005) & \\
\hline \multicolumn{4}{|l|}{ Amaranthaceae } \\
\hline Achyranthes japonica & Flor de barcia & > Raíz (agua); Bae et al. (1998) & \\
\hline Amaranthus spinosus & Quintonil & > Raíz (etanol); Wang y Huang (2005a) & \\
\hline Amaranthus viridis & Amaranto verde & > Tallo (etanol); Wang y Huang (2005a) & \\
\hline \multicolumn{4}{|l|}{ Anacardiaceae } \\
\hline Anacardium occidentale & Nuez de la India & $\begin{array}{l}\text { A Fruto y falso fruto (etanol); Kubo et al. } \\
\text { (1999) }\end{array}$ & $\begin{array}{l}\text { Fenoles; Kubo et al. } \\
\text { (1999) }\end{array}$ \\
\hline Pistacia lentiscos $\bullet$ & Lentisco & A Goma y resina; Marone et al. (2001) & \\
\hline Rhus chinensis & Agalla china & & $\begin{array}{l}\text { Tanino; Funatogawa et al. } \\
\text { (2004) }\end{array}$ \\
\hline Rhus javanica & Sumac & $\begin{array}{l}\text { ( Galla rhois [agallas] (agua); Bae et al. } \\
\text { (1998) }\end{array}$ & \\
\hline Rhus semialata & Sumac & > Tallo (etanol); Wang y Huang (2005a) & \\
\hline \multicolumn{4}{|l|}{ Apiaceae } \\
\hline Angelica coreana & - & > Raíz (agua); Bae et al. (1998) & \\
\hline Angelica dahurica & Bai zhi & ه Raíz (agua); Bae et al. (1998) & \\
\hline Angelica gigas & - & A Raíz (agua); Bae et al. (1998) & $\begin{array}{l}\text { Cumarinas; Bae et al. } \\
\text { (1998) }\end{array}$ \\
\hline Angelica tenuissima & - & > Raíz (agua); Bae et al. (1998) & \\
\hline Anthriscus sylvestris & Mirra & > Raíz (agua); Bae et al 1998 & \\
\hline Bupleurum chinense & Chai hu & A Parte aérea (etanol y agua); Li et al. (2005) & \\
\hline Bupleurum falcatum • & Thorow-wax & > Raíz (agua); Bae et al. (1998) & \\
\hline Carum carvi $\bullet$ & Alcaravea & A Semilla (metanol); Mahady et al. (2005) & $\begin{array}{l}\text { Aceite esencial; } \\
\text { Bergonzelli et al. (2003), } \\
\text { May et al. (2003) }\end{array}$ \\
\hline Centella asiatica $\bullet$ & $\begin{array}{l}\text { Centella asiática, } \\
\text { hierba de clavo }\end{array}$ & $\begin{array}{l}\text { Planta completa (etanol); Wang y } \\
\text { Huang (2005a) }\end{array}$ & \\
\hline Cnidium officinale & - & > Rizoma (agua); Bae et al. (1998) & \\
\hline Coriandrum sativum & Cilantro, culantro & $\begin{array}{l}\text { > Semilla (agua); O'Mahony et al. (2005) } \\
\text { \ Semilla (agua y etanol); Nostro et al. (2005) }\end{array}$ & \\
\hline Cuminum cyminum & Comino & 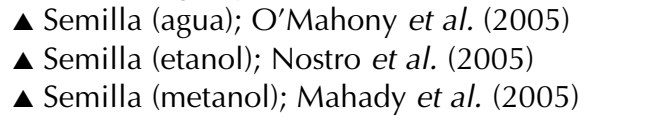 & \\
\hline Daucus carota & Zanahoria & & $\begin{array}{l}\text { Aceite esencial; } \\
\text { Bergonzelli et al. (2003) }\end{array}$ \\
\hline Foeniculum vulgare $\bullet$ & Hinojo & $\begin{array}{l}\text { - Fruto (metanol 70\%); Stamatis et al. (2003) } \\
\text { - Fruto (etanol); Li et al. (2005) } \\
\text { - Semilla (agua y etanol); Nostro et al. (2005) } \\
\text { - Semilla (metanol); Mahady et al. (2005) }\end{array}$ & \\
\hline Ligusticum chuanxiong & Chuang xiong & A Raíz (etanol); Li et al. (2005) & \\
\hline Petroselinum crispum & Perejil & $\begin{array}{l}\text { A Hoja (agua); O'Mahony et al. (2005) } \\
\text { > Parte aérea (metanol); Mahady et al. (2005) }\end{array}$ & \\
\hline Pimpinella anisum & $\begin{array}{l}\text { Pimpinela blanca, } \\
\text { anís }\end{array}$ & A —- (metanol); Mahady et al. (2005) & $\begin{array}{l}\text { Aceite esencial; } \\
\text { Bergonzelli et al. (2003) }\end{array}$ \\
\hline Trachyspermum copticum & Ajwain & 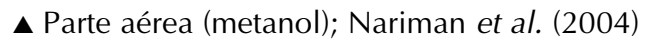 & \\
\hline
\end{tabular}




\begin{tabular}{|c|c|c|c|}
\hline $\begin{array}{l}\text { Familia y nombre } \\
\text { científico }\end{array}$ & Nombre común & Parte probada & $\begin{array}{l}\text { Grupos químicos } \\
\text { identificados }\end{array}$ \\
\hline \multicolumn{4}{|l|}{ Araceae } \\
\hline Pinellia ternata & Pinellia & > Tubérculo (agua); Bae et al. (1998) & \\
\hline \multicolumn{4}{|l|}{ Araliaceae } \\
\hline Panax ginseng • & Ginseng & $\begin{array}{l}\text { - Raíz (agua); Bae et al. (1998) } \\
\text { - Raíz (agua); Lee J.H. et al. (2004) }\end{array}$ & $\begin{array}{l}\text { Poliacetilenos y azúcares; } \\
\text { Bae et al. (2001a), } \\
\text { Belogortseva et al. (2000) }\end{array}$ \\
\hline Aralia cordata & Nardo japonés & > Raíz (agua); Bae et al. (1998) & \\
\hline \multicolumn{4}{|l|}{ Arecaceae } \\
\hline Areca catechu • & Areca, betel & > Semilla (etanol); Wang y Huang (2005a) & \\
\hline \multicolumn{4}{|l|}{ Aristolochiaceae } \\
\hline Aristolochia debilis & Ma dou ling & > Raíz (etanol); Li et al. (2005) & \\
\hline Aristolochia mallisima & - & > Hoja (etanol y agua); Li et al. (2005) & \\
\hline Aristolochia paucinervis & Candil & $\begin{array}{l}\text { A Hoja seca y rizoma (metanol y hexano); } \\
\text { Gadhi et al. (2001) }\end{array}$ & \\
\hline \multicolumn{4}{|l|}{ Asteraceae } \\
\hline Achillea ligustica & Mil hojas de ligur & $\begin{array}{l}\text { > Parte aérea (metanol 70\%); Stamatis et al. } \\
\text { (2003) }\end{array}$ & \\
\hline Achillea millefolium & Mil en rama & $\begin{array}{l}\text { A Parte aérea (metanol); Mahady et al. } \\
\text { (2005) }\end{array}$ & \\
\hline Anthemis altísima & Manzanilla altísima & & $\begin{array}{l}\text { Flavonoides, terpenos, } \\
\text { fenoles; Beil et al. (1995), } \\
\text { Konstantinopoulou et al. } \\
\text { (2003) }\end{array}$ \\
\hline Anthemis chia & Manzanilla olorosa & $\begin{array}{l}\text { Parte aérea (metanol 70\%); } \\
\text { Stamatis et al. (2003) }\end{array}$ & \\
\hline Anthemis melanolepis & Manzanilla & A - (metanol 70\%); Stamatis et al. (2003) & \\
\hline Anthemis tinctoria & Manzanilla amarilla & $\begin{array}{l}\text { Parte aérea (metanol 70\%); } \\
\text { Stamatis et al. (2003) }\end{array}$ & \\
\hline Anthemis tomentosa & Manzanilla & $\begin{array}{l}\text { Flor y hoja (metanol 70\%); } \\
\text { Stamatis et al. (2003) }\end{array}$ & \\
\hline Artemisia argvi & - & > Tallo y hoja (etanol); Wang y Huang (2005a) & \\
\hline Anthriscus sylvestris & Mirra & > Raíz (agua); Bae et al. (1998) & \\
\hline Artemisia capillaris & Yin chen hao & $\begin{array}{l}\text { > Planta completa (agua); Bae et al. (1998) } \\
\text { - (--); Lee J.H. et al. (2004) }\end{array}$ & \\
\hline Artemisia dracunculus & Tarragón & A Hoja (agua); O'Mahony et al. (2005) & $\begin{array}{l}\text { Aceite esencial; } \\
\text { Bergonzelli et al. (2003) }\end{array}$ \\
\hline Atractylodes japonica $\bullet$ & Packchul & > Rizoma (agua); Bae et al. (1998) & \\
\hline Bidens bipinnata & Aguja española & $\begin{array}{l}\text { > Planta completa (etanol); Wang y Huang } \\
\text { (2005a) }\end{array}$ & \\
\hline Bidens pilosa $\bullet$ & Aceitilla & > Tallo (etanol); Wang y Huang (2005a) & \\
\hline Calendula officinalis $\bullet$ & Mercadela & > Flor (metanol 70\%); Stamatis et al. (2003) & \\
\hline Centaurea affinis & - & $\begin{array}{l}\text { > Parte aérea (metanol 70\%); } \\
\text { Stamatis et al. (2003) }\end{array}$ & \\
\hline Centaurea pelia & - & A - $($ metanol 70\%); Stamatis et al. (2003) & \\
\hline Centaurea salonitana $\bullet$ & - & $\begin{array}{l}\text { Parte aérea (metanol 70\%); } \\
\text { Stamatis et al. (2003) }\end{array}$ & \\
\hline Centaurea solstitialis $\bullet$ & $\begin{array}{l}\text { Cardo estrella } \\
\text { amarilla }\end{array}$ & $\begin{array}{l}\text { A Parte herbácea (metanol y agua); } \\
\text { Yesilada et al. (1999) }\end{array}$ & \\
\hline Centaurea spinosa & Pincel & $\begin{array}{l}\text { Parte aérea (metanol 70\%); } \\
\text { Stamatis et al. (2003) }\end{array}$ & \\
\hline
\end{tabular}


ISRAel CASTILlo-JuÁREZ E IRMA Romero

\begin{tabular}{|c|c|c|c|}
\hline $\begin{array}{l}\text { Familia y nombre } \\
\text { científico }\end{array}$ & Nombre común & Parte probada & $\begin{array}{l}\text { Grupos químicos } \\
\text { identificados }\end{array}$ \\
\hline Centaurea thessala & - & $\boldsymbol{\Delta}$ - (metanol 70\%); Stamatis et al. (2003) & \\
\hline Chamomilla recutita & Manzanilla & A —- (metanol 70\%); Stamatis et al. (2003) & \\
\hline Chrysanthemun indicum & - & > Flor (agua); Bae et al. (1998) & \\
\hline Cichorium intybus $\bullet$ & Achicoria común & A Raíz (Etanol); Nostro et al. (2005) & \\
\hline Conyza albida & Cimonillo & A —- (metanol 70\%); Stamatis et al. (2003) & \\
\hline Conyza bonariensis & Rama negra & A - - (metanol 70\%); Stamatis et al. (2003) & \\
\hline Cynara scolymus & Alcachofa & A Hojas (agua y etanol); Nostro et al. (2005) & \\
\hline Dittrichia viscosa & Falsa cabeza amarilla & A - $($ metanol 70\%); Stamatis et al. (2003) & \\
\hline Dittrichia graveolens & Stinkwort & $\begin{array}{l}\text { Parte aérea (metanol 70\%); } \\
\text { Stamatis et al. (2003) }\end{array}$ & \\
\hline Entada abyssinica & Umusange & > Corteza (metanol); Fabry et al. (1996a) & \\
\hline Gnaphalium adnatum & - & $\begin{array}{l}\text { > Planta completa (metanol); Wang y Huang } \\
\text { (2005a) }\end{array}$ & \\
\hline Helichrysum stoechas & Perpetua, siempreviva & $\begin{array}{l}\text { Parte aérea (metanol 70\%); } \\
\text { Stamatis et al. (2003) }\end{array}$ & \\
\hline Inula verbascifolia & Inula & $\begin{array}{l}\text { Parte aérea (metanol 70\%); } \\
\text { Stamatis et al. (2003) }\end{array}$ & \\
\hline Inula viscosa & Inula & A - (agua y etanol 95\%); Tabak et al. (1996) & \\
\hline Matricaria aurea & - & > - (agua y etanol 95\%); Tabak et al. (1996) & \\
\hline Matricaria matricarioides & Mala hierba de piña & > Flor (agua); Annuk et al. (1999) & \\
\hline Matricaria recutita & Manzanilla alemana & $\begin{array}{l}\text { > Flor (agua); Annuk et al. (1999) } \\
\text { > Flor (metanol); Mahady et al. (2005) }\end{array}$ & $\begin{array}{l}\text { Aceite esencial; } \\
\text { Bergonzelli et al. (2003) }\end{array}$ \\
\hline Phagnalon graecum & Phagnalon & $\begin{array}{l}\text { Parte aérea (metanol 70\%); } \\
\text { Stamatis et al. (2003) }\end{array}$ & \\
\hline Saussurea lappa • & - & $\begin{array}{l}\text { - Raíz (agua); Bae et al. (1998) } \\
\text { ^ Raíz (etanol); Li et al. (2005) }\end{array}$ & \\
\hline Senecio scandens & Senecio & $\begin{array}{l}\text { > Planta completa (etanol); Wang y Huang } \\
\text { (2005a) }\end{array}$ & \\
\hline Senecio thapsoides & Senecio & $\begin{array}{l}\text { Parte aérea (metanol 70\%); } \\
\text { Stamatis et al. (2003) }\end{array}$ & \\
\hline Sonchus arvensis & Lechuguilla & $\begin{array}{l}\text { > Planta completa (etanol); Wang y Huang } \\
\text { (2005a) }\end{array}$ & \\
\hline Spilanthes mauritiana & - & > Raíz (metanol); Fabry et al. (1996a) & \\
\hline Vernonia cinerea & Chamorro & $\begin{array}{l}\text { Planta completa (etanol); Wang y Huang } \\
\text { (2005a) }\end{array}$ & \\
\hline Wikstroemia indica & - & > Corteza (etanol); Wang y Huang (2005a) & \\
\hline Xanthium brasilicum & Cardillo & A Parte aérea (metanol); Nariman et al. (2004) & \\
\hline Xanthium sibiricum & - & > Fruto (agua); Li et al. (2005) & \\
\hline Xanthium strumarium & Cardillo & > Planta completa (etanol); Wang y Huang (2005) & \\
\hline \multicolumn{4}{|l|}{ Betulaceae } \\
\hline Corylus heterophylla & Avellana siberiana & & $\begin{array}{l}\text { Taninos; Funatogawa et } \\
\text { al. (2004) }\end{array}$ \\
\hline \multicolumn{4}{|l|}{ Bignoniaceae } \\
\hline Tabebuia impetiginosa & Taheebo & > Corteza (metanol); Park et al. (2006) & $\begin{array}{l}\text { Antro y naftoquinonas; } \\
\text { Park et al. (2006) }\end{array}$ \\
\hline \multicolumn{4}{|l|}{ Bombacaceae } \\
\hline Bombax malabaricum & $\begin{array}{l}\text { Árbol de algodón } \\
\text { de seda roja }\end{array}$ & A Raíz (etanol 95\%); Wang y Huang (2005a) & \\
\hline \multicolumn{4}{|l|}{ Boraginaceae } \\
\hline Borago officinalis & Borraja & A Flor (agua); O'Mahony et al. (2005) & \\
\hline
\end{tabular}




\begin{tabular}{|c|c|c|c|}
\hline $\begin{array}{l}\text { Familia y nombre } \\
\text { científico }\end{array}$ & Nombre común & Parte probada & $\begin{array}{l}\text { Grupos químicos } \\
\text { identificados }\end{array}$ \\
\hline Ehretia acuminata & Árbol de kodo & > Raíz (etanol); Wang y Huang (2005a) & \\
\hline $\begin{array}{l}\text { Lithospermum } \\
\text { erythrorhizon }\end{array}$ & Mijo & > Raíz (agua); Bae et al. (1998) & \\
\hline \multicolumn{4}{|l|}{ Brassicaceae } \\
\hline Brassica oleracea $\bullet$ & Brócoli & & $\begin{array}{l}\text { Sulforofano; Fahey et al. } \\
\text { (2002), } \\
\text { Haristoy et al. (2003) }\end{array}$ \\
\hline Wasabia japonica & Wasabi & $\begin{array}{l}\text { A Raíz, corteza y hoja (éter anhidro); } \\
\text { Shin et al. (2004) }\end{array}$ & \\
\hline \multicolumn{4}{|l|}{ Burseraceae } \\
\hline Canarium album & Olivo blanco & > Raíz (etanol); Wang y Huang (2005a) & \\
\hline \multicolumn{4}{|l|}{ Campanulaceae } \\
\hline Platycodon grandiflorum & Flor de globo & > Raíz (agua); Bae et al. (1998) & \\
\hline \multicolumn{4}{|l|}{ Cannabaceae } \\
\hline Humulus lupulus & Lúpulo & > Flor (metanol 70\%); Stamatis et al. (2003) & \\
\hline \multicolumn{4}{|l|}{ Capparaceae } \\
\hline Cleome viscosa & Frijol cimarrón & வ Hoja (metanol); Bhamaraprevati et al. (2003) & \\
\hline \multicolumn{4}{|l|}{ Caprifoliaceae } \\
\hline Lonicera japonica & Madreselva japonesa & > Flor (agua); Bae et al. (1998) & \\
\hline Sambucus canadiensis & Baya de sauco & A Fruto (--); Chatterjee et al. (2004) & \\
\hline Sambucus chinensis & Sauco chino & $\begin{array}{l}\text { > Planta completa (etanol); Wang y Huang } \\
\text { (2005a) }\end{array}$ & \\
\hline Sambucus ebulus & Matapulgas, sauquillo & $\begin{array}{l}\text { Parte herbácea (agua y metanol); } \\
\text { Yesilada et al. (1999) }\end{array}$ & \\
\hline \multicolumn{4}{|l|}{ Caryophyllaceae } \\
\hline Cerastium candidissimum & $\begin{array}{l}\text { Oreja de ratón } \\
\text { plateada }\end{array}$ & A - $($ metanol 70\%); Stamatis et al. (2003) & \\
\hline Herniaria incana & - & $\begin{array}{l}\text { Parte aérea (metanol 70\%); } \\
\text { Stamatis et al. (2003) }\end{array}$ & \\
\hline \multicolumn{4}{|l|}{ Casuarinaceae } \\
\hline Casuarina stricta & Casuarina & & $\begin{array}{l}\text { Taninos; Funatogawa et } \\
\text { al. (2004) }\end{array}$ \\
\hline \multicolumn{4}{|l|}{ Chenopodiaceae } \\
\hline $\begin{array}{l}\text { Chenopodium } \\
\text { ambrosioides }\end{array}$ & Epazote & > Tallo y hoja (etanol); Wang y Huang (2005a) & \\
\hline \multicolumn{4}{|l|}{ Cistaceae } \\
\hline Cistus creticus & Estepa menorquina & $\begin{array}{l}\text { Flor y hoja (metanol 70\%); } \\
\text { Stamatis et al. (2003) }\end{array}$ & \\
\hline Cistus ladanigerus & Cistus & & $\begin{array}{l}\text { Aceite esencial; } \\
\text { Bergonzelli et al. (2003) }\end{array}$ \\
\hline Cistus laurifolius $\bullet$ & Estepa real & A Flor (metanol); Yesilada et al. (1999) & $\begin{array}{l}\text { Flavonoides; Ustun et al. } \\
(2006)\end{array}$ \\
\hline Cistus monspeliensis & Jaguarzo negro & $\begin{array}{l}\text { Flor y hoja (metanol 70\%); } \\
\text { Stamatis et al. (2003) }\end{array}$ & \\
\hline
\end{tabular}


ISRAEl CASTILlo-JuÁREZ E IRMA ROMERO

\begin{tabular}{|c|c|c|}
\hline $\begin{array}{l}\text { Familia y nombre } \\
\text { científico }\end{array}$ & Nombre común & Parte probada \\
\hline Cistus parviflorus & Rosa de roca & $\begin{array}{l}\text { Plor y hoja (metanol 70\%); } \\
\text { Stamatis et al. (2003) }\end{array}$ \\
\hline Cistus salvifolius & Rosa de roca & $\begin{array}{l}\text { Flor y hoja (metanol 70\%); } \\
\text { Stamatis et al. (2003) }\end{array}$ \\
\hline \multicolumn{3}{|l|}{ Clusiaceae } \\
\hline Hypericum amblycalyx & - & $\begin{array}{l}\text { Parte aérea(metanol 70\%); } \\
\text { Stamatis et al. (2003) }\end{array}$ \\
\hline Hypericum perforatum & Hierba de San Juan & A Flor (metanol); Yesilada et al. (1999) \\
\hline \multicolumn{3}{|l|}{ Combretaceae } \\
\hline Pteleopsis suberosa • & - & $\begin{array}{l}\text { A Corteza (metanol y agua); Germano et al. } \\
\text { (1998), De Pasquale et al. (1995) }\end{array}$ \\
\hline Terminalia chebula & Myrobalan negro & $\begin{array}{l}\text { - Corteza (metanol y agua); } \\
\text { Malekzadeh et al. (2001) }\end{array}$ \\
\hline Terminalia spinosa & - & $\begin{array}{l}\text { A Ramas superiores (metanol); } \\
\text { Fabry et al. (1996a) } \\
\text { வ Corteza (metanol); Fabry et al. (1996b) }\end{array}$ \\
\hline \multicolumn{3}{|l|}{ Commelinaceae } \\
\hline Murdannia bracteata & - & $\begin{array}{l}\text { > Planta completa (metanol); Wang y Huang } \\
\text { (2005a) }\end{array}$ \\
\hline
\end{tabular}

Cornaceae

Cornus officinalis Shan zhu yu

\section{Cucurbitaceae}

Momordica charantia

\section{Cupressaceae}

Cupressus sempervirens

Juniperus communis
Melón amargo

Ciprés

Enebro común
A Fruto (etanol); Nostro et al. (2005)

ه Fruto (metanol); Mahady et al. (2005)
Grupos químicos

identificados
Saponinas triterpénicas; De Leo et al. (2006)
Taninos; Funatogawa et al. (2004)

Aceite esencial; Bergonzelli et al. (2003) Aceite esencial; Bergonzelli et al. (2003) Terpeno; Nakanishi et al. (2005)

\section{Cycadaceae}

Cycas resoluta

Cycas siamensis

\section{Cyperaceae}

Cyperus rotundus

\section{Ebenaceae \\ Diospyros kaki}

Elaeagnaceae

Elaeagnus umbellata

Hippophae rhamnoides
Palma de sago<smiles>C=[IH]</smiles>

Coyolillo, coquito

Manzana del oriente

> Cáscara (diversas); Kawase et al. (2003)

Aceituna del otoño

Espino marino
Taninos; Yoshida et al. (2000), Funatogawa et al. (2004) Tanino; Funatogawa et al. (2004) 


\begin{tabular}{|c|c|c|c|}
\hline $\begin{array}{l}\text { Familia y nombre } \\
\text { científico }\end{array}$ & Nombre común & Parte probada & $\begin{array}{l}\text { Grupos químicos } \\
\text { identificados }\end{array}$ \\
\hline \multicolumn{4}{|l|}{ Ericaceae } \\
\hline Arctostaphylos uva-ursi & Manzanita & 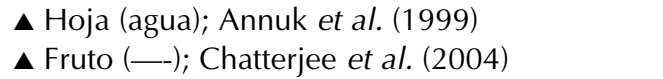 & \\
\hline Vaccinium vitis-ideae & Cereza negra & $\begin{array}{l}\text { A Hoja (agua); Annuk et al. (1999) } \\
\text { A Fruto (--); Chatterjee et al. (2004) }\end{array}$ & \\
\hline Vaccinium macrocarpon & Arándano agrio & $\begin{array}{l}-(-) \text {; Burger et al. (2000) } \\
\text { A Fruto (--); Chatterjee et al. (2004) } \\
\text { - - (-); Lin et al. (2005) }\end{array}$ & \\
\hline Vaccinium myrtillus & Arándano & A Fruto (--); Chatterjee et al. (2004) & \\
\hline Vaccinium uliginosum & Arándano & A Fruto (--); Chatterjee et al. (2004) & \\
\hline \multicolumn{4}{|l|}{ Euphorbiaceae } \\
\hline Bischofia javanica & Toog & > Tallo (etanol); Wang y Huang (2005a) & \\
\hline Croton lechleri & Sangre de grado & $\begin{array}{l}\text { - Látex y productos comerciales; } \\
\text { Ortiz et al. (2003), Tran et al. (2006) }\end{array}$ & \\
\hline Croton sublyratus $\bullet$ & Croton, plaunoi & & $\begin{array}{l}\text { Plaunotol; Koga et al. } \\
\text { (1996), Koga et al. (2002), } \\
\text { Takagi et al. (2000) }\end{array}$ \\
\hline Euphorbia hirta & $\begin{array}{l}\text { Hierba de la } \\
\text { golondrina }\end{array}$ & $\begin{array}{l}\text { > Planta completa (etanol); Wang y Huang } \\
\text { (2005a) }\end{array}$ & $\begin{array}{l}\text { Taninos; Funatogawa } \\
\text { et al. (2004) }\end{array}$ \\
\hline Phyllanthus urinaria & - & $\begin{array}{l}\text { Planta completa (etanol); Wang y Huang } \\
\text { (2005a) }\end{array}$ & \\
\hline \multicolumn{4}{|l|}{ Fabaceae } \\
\hline Abrus cantoniensis & - & A Hoja (metanol); Li et al. (2005) & \\
\hline $\begin{array}{l}\text { Astragalus } \\
\text { membranaceus }\end{array}$ & Astrágalo chino & $\begin{array}{l}\text { > Raíz (etanol); Li et al. (2005) } \\
\text { > Raíz (agua); Bae et al. (1998) }\end{array}$ & \\
\hline Cassia grandis & Carao, Iluvia rosa & А Hoja (metanol); Bhamarapravati et al. (2003) & \\
\hline Cassia obtusifolia & $\begin{array}{l}\text { Vaina o } \\
\text { capullo de oz }\end{array}$ & $\begin{array}{l}\text { \ Hojas (agua); Li et al. (2005) } \\
\text { > Semilla (agua); Bae et al. (1998) }\end{array}$ & \\
\hline Derris malaccensis & $\begin{array}{l}\text { Enredadera de } \\
\text { Nueva Guinea }\end{array}$ & & $\begin{array}{l}\text { Rotenoides; Takashima } \\
\text { et al. (2002), Isobe et al. } \\
(2002)\end{array}$ \\
\hline Dorycnium pentaphyllum & Bocha, socarrillo & $\begin{array}{l}\text { > Parte aérea (metanol 70\%); } \\
\text { Stamatis et al. (2003) }\end{array}$ & \\
\hline Flemingia philippinensis & - & > Tallo (etanol); Wang y Huang (2005a) & \\
\hline Glycyrrhiza aspera • & Orozús & A Parte aérea (mezcla); Nariman et al. (2004) & \\
\hline Glycyrrhiza glabra • & Orozús & 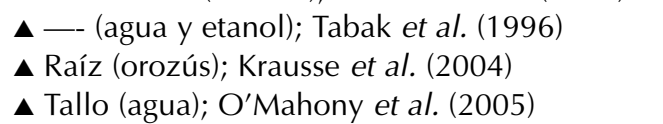 & $\begin{array}{l}\text { Flavonoides y saponinas; } \\
\text { Fukai et al. (2002), } \\
\text { Krausse et al. (2004) }\end{array}$ \\
\hline Glycyrrhiza Inflata • & Orozús & & $\begin{array}{l}\text { Flavonoides; Fukai et al. } \\
\text { (2002) }\end{array}$ \\
\hline Glycyrrhiza uralensis $\bullet$ & Orozús & $\begin{array}{l}\text { > Raíz (agua); Bae et al. (1998) } \\
\text { > Rizoma (etanol y agua); Li et al. (2005) } \\
\text { > Raíz (agua); Bae et al. (1998) }\end{array}$ & $\begin{array}{l}\text { Flavonoides y saponinas; } \\
\text { Fukai et al. (2002) }\end{array}$ \\
\hline Myroxylon peruiferum & Bálsamo de Perú & & $\begin{array}{l}\text { Flavonoides; Ohsaki et al. } \\
\text { (1999) }\end{array}$ \\
\hline Pueraria thunbergiana & Kudzu & > Raíz (agua); Bae et al. (1998) & $\begin{array}{l}\text { Flavonoides; Bae et al. } \\
\text { (2001b) }\end{array}$ \\
\hline Sophora flavescens • & Ku shen & $\begin{array}{l}\text { > Raíz (etanol); Wang y Huang (2005a) } \\
\text { > Raíz (etanol y agua); Li et al. (2005) }\end{array}$ & \\
\hline Spartium junceum • & Retama de olor & > Flor (agua y metanol); Yesilada et al. (1999) & \\
\hline $\begin{array}{l}\text { Trigonella foenum } \\
\text { graecum }\end{array}$ & Alhova & $\begin{array}{l}\text { > Semilla (etanol y agua); Li et al. (2005) } \\
\text { > Semilla (agua); O'Mahony et al. (2005) }\end{array}$ & \\
\hline
\end{tabular}


ISRAEl CASTILLO-JUÁREZ E IRMA ROMERO

\begin{tabular}{|c|c|c|c|}
\hline $\begin{array}{l}\text { Familia y nombre } \\
\text { científico }\end{array}$ & Nombre común & Parte probada & $\begin{array}{l}\text { Grupos químicos } \\
\text { identificados }\end{array}$ \\
\hline \multicolumn{4}{|l|}{ Fagaceae } \\
\hline Quercus aliena & Roble blanco oriental & & $\begin{array}{l}\text { Tanino; Funatogawa et al. } \\
\text { (2004) }\end{array}$ \\
\hline \multicolumn{4}{|l|}{ Fumariaceae } \\
\hline Corydalis yanhusuo & Yan hu suo & A Tallo (etanol); Li et al. (2005) & \\
\hline \multicolumn{4}{|l|}{ Gentianaceae } \\
\hline Gentiana lutea & Flor de hielo & வ Raíz (metanol); Mahady et al. (2005) & \\
\hline \multicolumn{4}{|l|}{ Geraniaceae } \\
\hline Geranium thunbergii & Geranio & & $\begin{array}{l}\text { Taninos; Funatogawa et } \\
\text { al. (2004) }\end{array}$ \\
\hline \multicolumn{4}{|l|}{ Ginkgoaceae } \\
\hline Ginkgo biloba & Ginkgo & $\begin{array}{l}\text { > Hoja (metanol 70\%); Stamatis et al. (2003) } \\
\text { > Hoja (metanol); Mahady et al. (2005) }\end{array}$ & \\
\hline \multicolumn{4}{|l|}{ Gramineae } \\
\hline Hordeum vulgare & Cebada & A Semilla (acuoso); Bae et al. (1998) & \\
\hline \multicolumn{4}{|l|}{ Grossulariaceae } \\
\hline Ribes nigrum & Grosella negra & $>\bullet$ Semillas (acetona); Lengsfeld et al. (2004a) & \\
\hline \multicolumn{4}{|l|}{ Juglandaceae } \\
\hline Juglans regia & Nogal & A Parte aérea (mezcla); Nariman et al. (2004) & \\
\hline \multicolumn{4}{|l|}{ Labiatae } \\
\hline Perilla sikokiana & - & > Parte herbácea (agua); Bae et al. (1998) & \\
\hline \multicolumn{4}{|l|}{ Lamiaceae } \\
\hline Acinos suaveolens & - & $\begin{array}{l}\text { Flor y hoja (metanol 70\%); } \\
\text { Stamatis et al. (2003) }\end{array}$ & \\
\hline Anisomeles indica & Fang feng cao & ^ Tallo (etanol 95\%); Wang y Huang (2005a) & \\
\hline Coridothymus capitatus & Timo & A —- (agua); Tabak et al. (1996) & \\
\hline Hyptis fasciculata & - & A Partes aéreas (—-); Isobe et al. (2006) & $\begin{array}{l}\text { Flavonoides; Isobe et al. } \\
(2006)\end{array}$ \\
\hline Lavandula angustifolia & Lavanda & A Flor (metanol); Mahady et al. (2005) & \\
\hline Majorana syrica & Zaatar & A - (agua y etanol 95\%); Tabak et al. (1996) & \\
\hline Melissa officinalis & $\begin{array}{l}\text { Melisa, toronjil, } \\
\text { cedrón }\end{array}$ & 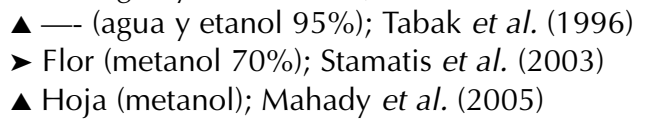 & \\
\hline Mentha arvensis & Menta japonesa & A Planta completa; Bae et al. (1998) & \\
\hline Mentha haplocalyx & Menta china & > Parte aérea (etanol); Li et al. (2005) & \\
\hline Mentha $\times$ piperita & Hierbabuena & $\begin{array}{l}\text { > Hoja (agua y etanol); Nostro et al. (2005) } \\
\text { × Hoja (metanol); Mahady et al. (2005) }\end{array}$ & $\begin{array}{l}\text { Aceites esenciales; } \\
\text { Imai et al. (2001), May } \\
\text { et al. (2003) }\end{array}$ \\
\hline Mentha spica & Menta & & $\begin{array}{l}\text { Aceites esenciales; } \\
\text { Imai et al. (2001) }\end{array}$ \\
\hline Micromeria juliana & Savory & > Hoja (metanol 70\%); Stamatis et al. (2003) & \\
\hline Nepeta argolica & - & $\begin{array}{l}\text { Parte aérea (metanol 70\%); } \\
\text { Stamatis et al. (2003) }\end{array}$ & $\begin{array}{l}\text { Aceites esenciales; } \\
\text { Kalpoutzakis et al. (2001) }\end{array}$ \\
\hline Nepeta camphorata & - & & $\begin{array}{l}\text { Aceites esenciales; } \\
\text { Kalpoutzakis et al. (2001) }\end{array}$ \\
\hline
\end{tabular}




\begin{tabular}{|c|c|c|c|}
\hline $\begin{array}{l}\text { Familia y nombre } \\
\text { científico }\end{array}$ & Nombre común & Parte probada & $\begin{array}{l}\text { Grupos químicos } \\
\text { identificados }\end{array}$ \\
\hline Ocimum basilicum • & Albahaca & A —- (metanol 70\%); Stamatis et al. (2003) & $\begin{array}{l}\text { Aceite esencial; } \\
\text { Bergonzelli et al. (2003) }\end{array}$ \\
\hline Origanum dictamnus & Orégano & A —- (metanol 70\%); Stamatis et al. (2003) & \\
\hline Origanum majorana & Mejorana, mayorana & 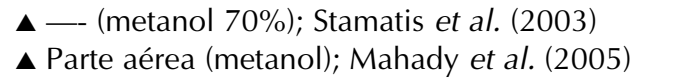 & \\
\hline Origanum vulgare & Orégano & 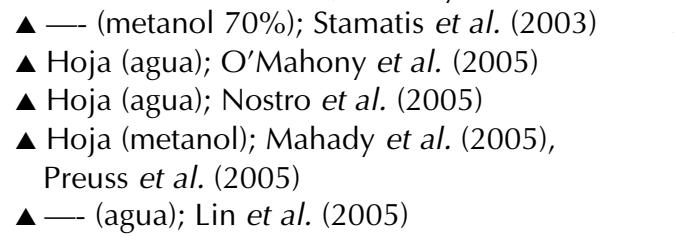 & $\begin{array}{l}\text { Aceite esencial; } \\
\text { Bergonzelli et al. (2003) }\end{array}$ \\
\hline Rabdosia trichocarpa & -- & & $\begin{array}{l}\text { Terpeno; Kadota et al. } \\
\text { (1997) }\end{array}$ \\
\hline Rosmarinus officinalis $\bullet$ & Romero & $\begin{array}{l}\text { - - (agua y etanol 95\%); Tabak et al. (1996) } \\
\text { - Hoja (metanol 70\%); Stamatis et al. (2003) } \\
\text { × Hoja (etanol); Nostro et al. (2005) } \\
\text { × Hoja (metanol); Mahady et al. (2005) }\end{array}$ & \\
\hline Salvia fruticosa & $\begin{array}{l}\text { Artemisa, salvia } \\
\text { griega }\end{array}$ & $\begin{array}{l}\text { > Parte aérea (metanol 70\%); } \\
\text { Stamatis et al. (2003) }\end{array}$ & \\
\hline Salvia officinalis & Salvia & $\begin{array}{l}\text { - - (agua y etanol 95\%); Tabak et al. (1996) } \\
\text { வ Hoja (agua); O'Mahony et al. (2005) } \\
\text { வ Hoja (agua y etanol); Nostro et al. (2005) } \\
\text { × Hoja (metanol); Mahady et al. (2005) }\end{array}$ & $\begin{array}{l}\text { Aceite esencial; } \\
\text { Bergonzelli et al. (2003) }\end{array}$ \\
\hline Salvia pomifera & Salvia manzana & > Parte aérea (metanol 70\%); Stamatis et al. (2003) & \\
\hline Salvia sclarea & Salvia & & $\begin{array}{l}\text { Aceite esencial; } \\
\text { Bergonzelli et al. (2003) }\end{array}$ \\
\hline Satureja montana & Ajedrea & & $\begin{array}{l}\text { Aceite esencial; } \\
\text { Bergonzelli et al. (2003) }\end{array}$ \\
\hline Satureja parnassica & & & $\begin{array}{l}\text { Aceite esencial; Tzakou } \\
\text { y Skaltsa (2003) }\end{array}$ \\
\hline Scutellaria albida & - & $\begin{array}{l}\text { Parte aérea (metanol 70\%); } \\
\text { Stamatis et al. (2003) }\end{array}$ & \\
\hline Scutellaria baicalensis & - & A Raíz (agua); Bae et al. (1998) & \\
\hline Scutellaria barbata & - & > Planta completa (etanol y agua); Li et al. (2005) & \\
\hline Scutellaria sieberi & - & $\begin{array}{l}\text { Parte aérea (metanol 70\%); } \\
\text { Stamatis et al. (2003) }\end{array}$ & \\
\hline Sideritis italica & Pasto de montaña & $\begin{array}{l}\text { A Parte aérea y flor (aceite esencial); } \\
\text { Basile et al. (2006) }\end{array}$ & \\
\hline Stachys alopecurus & - & A —- (metanol 70\%); Stamatis et al. (2003) & \\
\hline Stachys candida & - & $\begin{array}{l}\text { > Parte aérea (metanol 70\%); } \\
\text { Stamatis et al. (2003) }\end{array}$ & \\
\hline Stachys chrysantha & - & > Hoja (metanol 70\%); Stamatis et al. (2003) & \\
\hline Stachys cretica & - & $\begin{array}{l}\text { Parte aérea (metanol 70\%); } \\
\text { Stamatis et al. (2003) }\end{array}$ & \\
\hline Stachys germanica & - & $\begin{array}{l}\text { - Flor y hoja (metanol 70\%); } \\
\text { Stamatis et al. (2003) }\end{array}$ & \\
\hline Stachys ionica & -- & $\begin{array}{l}\text { Parte aérea (metanol 70\%); } \\
\text { Stamatis et al. (2003) }\end{array}$ & \\
\hline Stachys menthifolia & - & $\begin{array}{l}\text { > Parte aérea (metanol 70\%); } \\
\text { Stamatis et al. (2003) }\end{array}$ & \\
\hline Stachys officinalis & - & $\begin{array}{l}\text { Parte aérea (metanol 70\%); } \\
\text { Stamatis et al. (2003) }\end{array}$ & \\
\hline Stachys melangavica & - & $\begin{array}{l}\text { Parte aérea (metanol 70\%); } \\
\text { Stamatis et al. (2003) }\end{array}$ & \\
\hline
\end{tabular}


ISRAEl CASTILlo-JuÁREZ E IRMA ROMERO

\begin{tabular}{|c|c|c|c|}
\hline $\begin{array}{l}\text { Familia y nombre } \\
\text { científico }\end{array}$ & Nombre común & Parte probada & $\begin{array}{l}\text { Grupos químicos } \\
\text { identificados }\end{array}$ \\
\hline Stachys scyronica & 一 & \multirow{6}{*}{\multicolumn{2}{|c|}{ 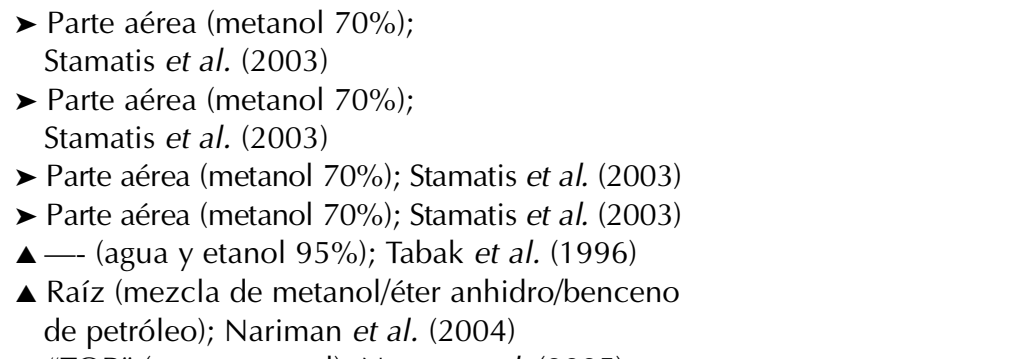 }} \\
\hline Stachys argolica & - & & \\
\hline Teucrium flavum & Tomillo & & \\
\hline Thymus atticus & Tomillo & & \\
\hline Thymus citroidorus & Tomillo & & \\
\hline Thymus kotschyanus & Tomillo & & \\
\hline Thymus serpyllum & Tomillo & ム "TOP" (agua y etanol); Nostro et al. (2005) & \\
\hline Thymus vulgaris & Tomillo & A-- (agua y etanol 95\%); Tabak et al. (1996) & $\begin{array}{l}\text { Aceite esencial; } \\
\text { Bergonzelli et al. (2003) }\end{array}$ \\
\hline Thymus zygis & Tomillo rojo & & $\begin{array}{l}\text { Aceite esencial; } \\
\text { Bergonzelli et al. (2003) }\end{array}$ \\
\hline \multicolumn{4}{|l|}{ Lauraceae } \\
\hline Cinnamomum cassia $\bullet$ & Canela china & $\begin{array}{l}\text { A Ramas pequeñas (agua); Bae et al. (1998) } \\
\text { A Corteza (etanol 95\%); Tabak et al. (1999) }\end{array}$ & $\begin{array}{l}\text { Cinamaldehido, eugenol; } \\
\text { Tabak et al. (1999) }\end{array}$ \\
\hline Cinnamomum verum & Canela de Ceilán & 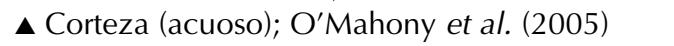 & \\
\hline Cinnamomum zeylanicum & Canela & $\begin{array}{l}\Delta-\text { - (Agua y etanol 95\%); Tabak et al. (1996) } \\
\Delta \text { Corteza (etanol); Nostro et al. (2005) }\end{array}$ & $\begin{array}{l}\text { Aceite esencial; } \\
\text { Bergonzelli et al. (2003) }\end{array}$ \\
\hline Laurus nobilis $\bullet$ & Laurel & $\begin{array}{l}\text { > - (agua y etanol 95\%); Tabak et al. (1996) } \\
\text { > Hoja (metanol 70\%); Stamatis et al. (2003) } \\
\text { × Hoja (metanol); Mahady et al. (2005) }\end{array}$ & \\
\hline Lindera strychnifolia & Wu yao & > Raíz (etanol); Li et al. (2005) & \\
\hline Litsea cubeba & $\begin{array}{l}\text { Pimienta de la } \\
\text { montaña }\end{array}$ & > Tallo (etanol); Wang y Huang (2005a) & \\
\hline Litsea elliptica & Medang & A Hoja (metanol); Bhamarapravati et al. (2003) & \\
\hline Sassafras officinale & Sassafras & & $\begin{array}{l}\text { Aceite esencial; } \\
\text { Bergonzelli et al. (2003) }\end{array}$ \\
\hline \multicolumn{4}{|l|}{ Lecythidaceae } \\
\hline Barringtonia acutangula & Nuez cortada & வ Hoja (metanol); Bhamarapravati et al. (2003) & \\
\hline \multicolumn{4}{|l|}{ Liliaceae } \\
\hline Allium ascalonicum & Ascalonia, ajo & A Hoja (metanol); Adeniyi-Anyiam (2004) & \\
\hline Allium sativum • & Ajo común & $\begin{array}{l}\text { A Fruto (acetona, etanol); limuro et al. (2002) } \\
\text { > Bulbo (agua); O'Mahony et al. (2005) } \\
\text { > Fruto (agua y etanol); Tabak et al. (1996) }\end{array}$ & $\begin{array}{l}\text { Tiosulfonatos; } \\
\text { (Referencias en el texto) }\end{array}$ \\
\hline Aloe vera $\bullet$ & Sávila & - —- (—-); Prabjone et al. (2006) & \\
\hline Fritillaria thunbergii & Zhe bei mu & $\begin{array}{l}\text { - Bulbo (agua); Bae et al. (1998) } \\
\text { \ Tallo (agua y etanol); Li et al. (2005) }\end{array}$ & \\
\hline Liriope platyphylla & - & > Tubérculo (agua); Bae et al. (1998) & \\
\hline Veratrum (género) & Ballestera & & $\begin{array}{l}\text { Alcaloides; Tezuka et al. } \\
\text { (1999) }\end{array}$ \\
\hline \multicolumn{4}{|l|}{ Lithraceae } \\
\hline Lafoensia pacari & Mangava-brava & > —- (metanol); Da Mota et al. (2006) & \\
\hline \multicolumn{4}{|l|}{ Magnoliaceae } \\
\hline Illicium verum & Anís estrella & $\begin{array}{l}\text { - Fruto (metanol 70\%); Stamatis et al. (2003) } \\
\text { A Fruto (metanol); Mahady et al. (2005) }\end{array}$ & \\
\hline Magnolia officinalis & Magnolia china & 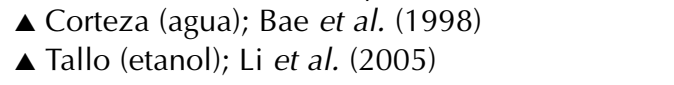 & $\begin{array}{l}\text { Magnolol; Bae et al. } \\
\text { (1998) }\end{array}$ \\
\hline
\end{tabular}




\begin{tabular}{|c|c|c|c|}
\hline $\begin{array}{l}\text { Familia y nombre } \\
\text { científico }\end{array}$ & Nombre común & Parte probada & $\begin{array}{l}\text { Grupos químicos } \\
\text { identificados }\end{array}$ \\
\hline Magnolia sieboldii & Magnolia oyama & A Corteza (metanol); Park et al. (1997) & $\begin{array}{l}\text { Costunolida; Park et al. } \\
\text { (1997) }\end{array}$ \\
\hline Schisandra chinensis & Wu-wei-zi & $\begin{array}{l}\text { A Fruto (etanol); Li et al. (2005) } \\
\text { > Fruto (agua); Bae et al. (1998) }\end{array}$ & \\
\hline \multicolumn{4}{|l|}{ Malpighiaceae } \\
\hline Malpighia emarginata & Cereza de Barbados & A Fruto (hexano); Motohashi et al. (2004) & \\
\hline \multicolumn{4}{|l|}{ Malvaceae } \\
\hline Abelmoschus esculentus & Planta de quingombó & $\begin{array}{l}\text { - Fruto (agua); Lengsfeld et al. (2004a) } \\
\text { - Fruto (jugo); Lengsfeld et al. (2004b) }\end{array}$ & \\
\hline Hibiscus muthtabilis & -- & $\begin{array}{l}\text { Planta completa (etanol); } \\
\text { Wang y Huang (2005a) }\end{array}$ & \\
\hline Sida rhombifolia & Barbarisco & > Planta completa (etanol); Wang y Huang (2005a) & \\
\hline \multicolumn{4}{|l|}{ Melastomataceae } \\
\hline Melastoma candidum & Melastoma asiática & > Tallo y raíz (etanol); Wang y Huang (2005a) & $\begin{array}{l}\text { Tanino; Funatogawa et al. } \\
\text { (2004) }\end{array}$ \\
\hline \multicolumn{4}{|l|}{ Meliaceae } \\
\hline Azadirachta indica • & Árbol de neem & $\begin{array}{l}\text { Corteza (metanol) y hojas (metanol); } \\
\text { Fabry et al. (1996a) }\end{array}$ & \\
\hline Melia toosendan & Chuan lian zi & > Fruto (etanol y agua); Li et al. (2005) & \\
\hline \multicolumn{4}{|l|}{ Menispermaceae } \\
\hline Coscinium fenestratum & $\begin{array}{l}\text { Falso columbo de } \\
\text { Ceilán }\end{array}$ & A Raíz (agua); O’Mahony et al. (2005) & \\
\hline Tinospora sagittata & Gagnep & > Raíz (etanol y agua); Li et al. (2005) & \\
\hline \multicolumn{4}{|l|}{ Musaceae } \\
\hline Musa sapientum & Plátano & > Fruto (metanol); Goel et al. (2001) & \\
\hline \multicolumn{4}{|l|}{ Myristicaceae } \\
\hline Myristica fragans & Nuez moscada & 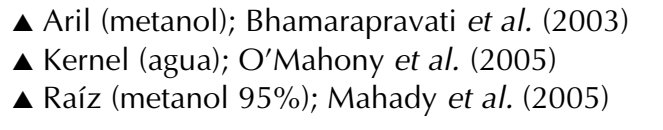 & \\
\hline \multicolumn{4}{|l|}{ Myrtaceae } \\
\hline Eucalyptus globosa & Eucalipto & & $\begin{array}{l}\text { Aceite esencial; } \\
\text { Bergonzelli et al. (2003) }\end{array}$ \\
\hline Eucalyptus spp. & Eucalipto & & $\begin{array}{l}\text { Taninos; Funatogawa et } \\
\text { al. (2004) }\end{array}$ \\
\hline Eugenia caryophyllata & Clavo & $\begin{array}{l}\text { A Flor (agua); Bae et al. (1998); } \\
\text { (agua y metanol); Li et al. (2005) }\end{array}$ & $\begin{array}{l}\text { Aceite esencial; } \\
\text { Bergonzelli et al. (2003) }\end{array}$ \\
\hline Leptospermum scoparium & Manuka & & $\begin{array}{l}\text { Aceite esencial; } \\
\text { Bergonzelli et al. (2003) }\end{array}$ \\
\hline Melaleuca leucadendron & Maleleuca & & $\begin{array}{l}\text { Polifenol y terpeno; } \\
\text { Funatogawa et al. (2004) }\end{array}$ \\
\hline Melaleuca quinquenervia & Malelauca & A Hoja (metanol); Bhamarapravati et al. (2003) & \\
\hline Melaleuca alternifolia & Árbol de té & & $\begin{array}{l}\text { Aceite esencial; } \\
\text { Bergonzelli et al. (2003) }\end{array}$ \\
\hline Psidium guajava & Guayabo & > Hoja (etanol); Wang y Huang (2005a) & $\begin{array}{l}\text { Tanino; Funatogawa et } \\
\text { al. (2004) }\end{array}$ \\
\hline Syzygium aromaticum & Clavo & A Hoja (metanol); Bhamarapravati et al. (2003) & \\
\hline
\end{tabular}


ISRAEl CASTILlo-JuÁREZ E IRMA ROMERO

\begin{tabular}{|c|c|c|c|}
\hline $\begin{array}{l}\text { Familia y nombre } \\
\text { científico }\end{array}$ & Nombre común & Parte probada & $\begin{array}{l}\text { Grupos químicos } \\
\text { identificados }\end{array}$ \\
\hline \multicolumn{4}{|l|}{ Oleaceae } \\
\hline Forsythia viridissima & Mimosa de París & > Fruto (agua); Bae et al. (1998) & \\
\hline Ligustrum vulgare & Trueno & 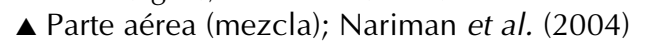 & \\
\hline Ximenia caffra & Ciruela agria grande & A Raíz (metanol); Fabry et al. (1996a) & \\
\hline \multicolumn{4}{|l|}{ Onagraceae } \\
\hline Ludwigia octovalvis & Hierba de clavo & > Tallo (etanol); Wang y Huang (2005a) & \\
\hline Oenothera stricta & - & & $\begin{array}{l}\text { Taninos; Funatogawa } \\
\text { et al. (2004) }\end{array}$ \\
\hline \multicolumn{4}{|l|}{ Opocynaceae } \\
\hline Catharanthus roseus & Cielo razo & > Planta completa (etanol); Wang y Huang (2005a) & \\
\hline \multicolumn{4}{|l|}{ Orchidaceae } \\
\hline Bletilla formosana & Orquídea blanca & > Tallo (etanol); Wang y Huang (2005a) & \\
\hline Bletilla striata & Orquídea jacinto & > Tallo (etanol); Li et al. (2005) & \\
\hline \multicolumn{4}{|l|}{ Papaveraceae } \\
\hline Sanguinaria canadensis & $\begin{array}{l}\text { Sanguinaria de } \\
\text { Canadá }\end{array}$ & 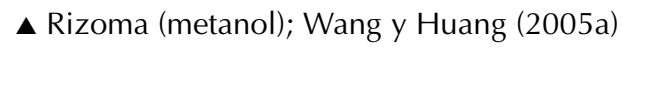 & $\begin{array}{l}\text { Alcaloides; Mahady } \\
\text { et al. (2003a) }\end{array}$ \\
\hline \multicolumn{4}{|l|}{ Passifloraceae } \\
\hline Passiflora incarnata & Pasiflora & 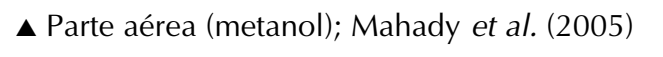 & \\
\hline \multicolumn{4}{|l|}{ Pinaceae } \\
\hline Abies maritima & Pino & & $\begin{array}{l}\text { Aceite esencial; } \\
\text { Bergonzelli et al. (2003) }\end{array}$ \\
\hline Cedrus libani & Cedro del Líbano & A Cono (metanol); Yesilada et al. (1999) & \\
\hline \multicolumn{4}{|l|}{ Piperaceae } \\
\hline Piper longum & Pimienta & $\begin{array}{l}\text { > Estaca (etanol y agua); Li et al. (2005) } \\
\text { \ Semilla (agua); O'Mahony et al. (2005) }\end{array}$ & \\
\hline Piper nigrum & Pimienta negra & > Semilla y fruto (agua); O'Mahony et al. (2005) & \\
\hline Pothomorphe umbellata & $\begin{array}{l}\text { Santa María, } \\
\text { cordoncillo }\end{array}$ & & $\begin{array}{l}\text { Alcaloides y flavonoides; } \\
\text { Isobe et al. (2002) }\end{array}$ \\
\hline \multicolumn{4}{|l|}{ Plumbaginaceae } \\
\hline Plumbago zeylanica & - & $\begin{array}{l}\text { வ Tallo (etanol, agua, acetona); } \\
\text { Wang y Huang (2005a) }\end{array}$ & $\begin{array}{l}\text { Plumbagina; Wang y } \\
\text { Huang }(2005 a, b)\end{array}$ \\
\hline \multicolumn{4}{|l|}{ Poaceae } \\
\hline Cymbopagon citratus & Té limón & & $\begin{array}{l}\text { Aceite esencial; } \\
\text { Bergonzelli et al. (2003), } \\
\text { Ohno et al. (2003) }\end{array}$ \\
\hline Setaria palmfolia & - & > Planta completa (etanol); Wang y Huang (2005a) & \\
\hline \multicolumn{4}{|l|}{ Polygonaceae } \\
\hline Polygonum chinense & - & > Raíz (etanol); Wang y Huang (2005a) & \\
\hline Polygonum senticosum & - & $\begin{array}{l}\text { Planta completa (etanol); Wang y } \\
\text { Huang (2005a) }\end{array}$ & \\
\hline Polygonum tinctorium & Indico japonés & & $\begin{array}{l}\text { Alcaloides y flavonoides; } \\
\text { Kataoka et al. (2001), } \\
\text { Hashimoto et al. (1999) }\end{array}$ \\
\hline
\end{tabular}




\begin{tabular}{|c|c|c|c|}
\hline $\begin{array}{l}\text { Familia y nombre } \\
\text { científico }\end{array}$ & Nombre común & Parte probada & $\begin{array}{l}\text { Grupos químicos } \\
\text { identificados }\end{array}$ \\
\hline Rheum emodi & $\begin{array}{l}\text { Ruibarbo del } \\
\text { Himalaya }\end{array}$ & > Rizomas (agua); Ibrahim et al. (2006) & \\
\hline Rheum palmatum & Ruibarbo de china & A Rizoma (agua); Bae et al. (1998) & \\
\hline \multicolumn{4}{|l|}{ Polyporaceae } \\
\hline Poria cocos & Poria & $\begin{array}{l}>\text { - (agua); Bae et al. (1998) } \\
\text { > Raíz (etanol y agua); Li et al. (2005) }\end{array}$ & \\
\hline \multicolumn{4}{|l|}{ Primulaceae } \\
\hline Lysimachia christinae & Jin qian cao & A Planta completa (etanol); Li et al. (2005) & \\
\hline \multicolumn{4}{|l|}{ Ranunculaceae } \\
\hline Cimicifuga heracleifolia & Bugbane & > Rizoma (agua); Bae et al. (1998) & \\
\hline Coptidis japonica & Ohren & A Rizoma (agua); Bae et al. (1998) & $\begin{array}{l}\text { Alcaloide; Bae et al. } \\
\text { (1998) }\end{array}$ \\
\hline Hydrastis canadensis & Cúrcuma canadiense & A Rizoma (metanol); Mahady et al. (2003a) & $\begin{array}{l}\text { Alcaloides; Mahady et al. } \\
\text { (2003a) }\end{array}$ \\
\hline Nigella sativa & Neguilla & A Semilla (agua); O'Mahony et al. (2005) & \\
\hline Paeonia albiflora & Peonia china & > Raíz (agua); Bae et al. (1998) & \\
\hline Paeonia montana & Peonia & > Corteza (agua); Bae et al. (1998) & \\
\hline \multicolumn{4}{|l|}{ Rosaceae } \\
\hline Agrimonia pilosa & Agrimonia china & $\begin{array}{l}\text { Planta completa (etanol); Wang y } \\
\text { Huang (2005a) }\end{array}$ & $\begin{array}{l}\text { Taninos; Funatogawa } \\
\text { et al. (2004) }\end{array}$ \\
\hline Cowania mexicana & Chivatillo & & $\begin{array}{l}\text { Taninos; Funatogawa } \\
\text { et al. (2004) }\end{array}$ \\
\hline Eriobotrya japonica & Níspero & & $\begin{array}{l}\text { Terpeno; Funatogawa } \\
\text { et al. (2004) }\end{array}$ \\
\hline Fragaria spp. & Fresa & $\Delta$ Fruto (—-); Chatterjee et al. (2004) & \\
\hline Malus sylvestris & Manzana & & $\begin{array}{l}\text { Protocianidinas; } \\
\text { Funatogawa et al. (2004) }\end{array}$ \\
\hline Prunus armeniaca & Chabacano & > Semilla (agua); Bae et al. (1998) & \\
\hline Prunus avium & Cerezo & $\begin{array}{l}\text { A Pedúnculo (agua y etanol); } \\
\text { Nostro et al. (2005) }\end{array}$ & \\
\hline Prunus mume & Chabacano japonés & வ Jugo del fruto; Otsuka et al. (2005) & $\begin{array}{l}\text { Siringaresinol; Miyazawa } \\
\text { et al. (2006) }\end{array}$ \\
\hline Rosa rugosa & Rosa de ramanas & & $\begin{array}{l}\text { Taninos; Funatogawa } \\
\text { et al. (2004) }\end{array}$ \\
\hline Rubus idaeus & Frambuesa & A Fruto (—-); Chatterjee et al. (2004) & \\
\hline \multicolumn{4}{|l|}{ Rubiaceae } \\
\hline Gardenia jasminoides & Gardenia & > Fruto (agua); Bae et al. (1998) & \\
\hline Paederia scandens & - & A Planta completa; Wang y Huang (2005a) & \\
\hline \multicolumn{4}{|l|}{ Rutaceae } \\
\hline Aegle marmelos $\bullet$ & Membrillo de Bengala & > Raíz (agua); O’Mahony et al. (2005) & $\begin{array}{l}\text { Ácido cinámico; Epifano } \\
\text { et al. (2006) }\end{array}$ \\
\hline Boronia pinnata & & & $\begin{array}{l}\text { Ácido boropínico; Epifano } \\
\text { et al. (2006) }\end{array}$ \\
\hline Citrus aurantium $\bullet$ & Naranjo amargo & > Fruto (agua); Bae et al. (1998) & $\begin{array}{l}\text { Aceite esencial; } \\
\text { Bergonzelli et al. (2003) }\end{array}$ \\
\hline Citrus limonum & Limón & & $\begin{array}{l}\text { Aceite esencial; } \\
\text { Bergonzelli et al. (2003) }\end{array}$ \\
\hline
\end{tabular}


ISRAEl CASTILlO-JUÁREZ E IRMA ROMERO

\begin{tabular}{|c|c|c|c|}
\hline $\begin{array}{l}\text { Familia y nombre } \\
\text { científico }\end{array}$ & Nombre común & Parte probada & $\begin{array}{l}\text { Grupos químicos } \\
\text { identificados }\end{array}$ \\
\hline Citrus $\times$ paradisi & Toronja & & $\begin{array}{l}\text { Aceite esencial; } \\
\text { Bergonzelli et al. (2003) }\end{array}$ \\
\hline Citrus reticulata & Mandarina & ه Cáscara del fruto (etanol); Li et al. (2005) & \\
\hline Citrus sinensis & & & $\begin{array}{l}\text { Ácido cinámico; Epifano } \\
\text { et al. (2006) }\end{array}$ \\
\hline Citrus sudachi & Sudachi, limón & A Cáscara (metanol); Nakagawa et al. (2006) & $\begin{array}{l}\text { Sudachitina; Nakagawa } \\
\text { et al. (2006) }\end{array}$ \\
\hline Evodiae rutaecarpa & Gosyuyu & $\begin{array}{l}\text { A Fruto (metanol); Rho et al. (1999) } \\
\text { A Fruto (metanol) (éter de petróleo); } \\
\text { Hamasaki et al. (2000) }\end{array}$ & $\begin{array}{l}\text { Quinolonas; Tominaga et } \\
\text { al. (2002), Hamasaki et al. } \\
\text { (2000), Rho et al. (1999) }\end{array}$ \\
\hline Phellodendron amurense $\bullet$ & Árbol de Amur & A Corteza (agua); Bae et al. (1998) & \\
\hline Poncirus trifoliata & Naranjo trifoliado & > Fruto (agua); Bae et al. (1998) & $\begin{array}{l}\text { Flavonoides; Kim et al. } \\
\text { (1999), Bae et al. (1999) }\end{array}$ \\
\hline Zanthoxylum nitidum & - & > Raíz (etanol); Wang y Huang (2005a) & \\
\hline \multicolumn{4}{|l|}{ Santalaceae } \\
\hline Santalum album • & Sándalo & & Terpenos; Ochi et al. (2005) \\
\hline \multicolumn{4}{|l|}{ Sapindaceae } \\
\hline Sapindus mukorossi & Ritha, aritha & $\begin{array}{l}\text { Pericarpo del fruto (agua); } \\
\text { Ibrahim et al. (2006) }\end{array}$ & \\
\hline \multicolumn{4}{|l|}{ Saururaceae } \\
\hline Houttuynia cordata & Planta camaleón & $\begin{array}{l}\text { Planta completa (etanol); Wang y } \\
\text { Huang (2005a) }\end{array}$ & \\
\hline \multicolumn{4}{|l|}{ Scrophulariaceae } \\
\hline Bacopa monnieri & Rasayana & A Planta completa (metanol); Goel et al. (2003) & \\
\hline \multicolumn{4}{|l|}{ Simaroubaceae } \\
\hline Harrisonia abyssinica & - & A Raíz (metanol); Fabry et al. (1996a) & \\
\hline \multicolumn{4}{|l|}{ Solanaceae } \\
\hline Capsicum (género) • & Chile & & $\begin{array}{l}\text { Capsaicina; Jones et al. } \\
\text { (1997) }\end{array}$ \\
\hline Capsicum annuum & Chile & $\begin{array}{l}\text { A Fruto (agua); O'Mahony et al. (2005) } \\
\text { > Fruto (varios); Motohashi et al. (2003) }\end{array}$ & $\begin{array}{l}\text { Flavonoide; Chung et al. } \\
\text { (2001) } \\
\text { Diterpeno; De Marino } \\
\text { et al. (2006) }\end{array}$ \\
\hline Lycium chinense & - & A Fruto (agua); Bae et al. (1998) & \\
\hline Solanum nigrum & Hierba mora & $\begin{array}{l}\text { Planta completa (etanol); Wang y } \\
\text { Huang (2005a) }\end{array}$ & \\
\hline Solanum surattense & $\begin{array}{l}\text { Ela battu } \\
\text { (Nightshade) }\end{array}$ & > Fruto y raíz (agua); O’Mahony et al. (2005) & \\
\hline Solanum xanthocarpum & Katu val batu & A Planta completa; O'Mahony et al. (2005) & \\
\hline \multicolumn{4}{|l|}{ Sterculiaceae } \\
\hline Theobroma сасао & Cacao & & $\begin{array}{l}\text { Protocianidinas; } \\
\text { Funatogawa et al. (2004) }\end{array}$ \\
\hline \multicolumn{4}{|l|}{ Theaceae } \\
\hline Camellia sinensis $\bullet$ & Té negro, té verde & $\begin{array}{l}\text { > Hojas (agua); O'Mahony et al. (2005) } \\
\text { × Té de catequinas; Imai et al. (2001) }\end{array}$ & $\begin{array}{l}\text { Flavonoides; Mabe et al. } \\
\text { (1999), Yee et al. (2000), } \\
\text { Funatogawa et al. (2004) }\end{array}$ \\
\hline
\end{tabular}




\begin{tabular}{|c|c|c|c|}
\hline $\begin{array}{l}\text { Familia y nombre } \\
\text { científico }\end{array}$ & Nombre común & Parte probada & $\begin{array}{l}\text { Grupos químicos } \\
\text { identificados }\end{array}$ \\
\hline Camelia japonica & - & & $\begin{array}{l}\text { Taninos; Funatogawa } \\
\text { et al. (2004) }\end{array}$ \\
\hline Thea chinensis & - & > Hojas (metanol 70\%); Stamatis et al. (2003) & \\
\hline \multicolumn{4}{|l|}{ Tiliaceae } \\
\hline Tilia platyphyllos & Tilo de hojas grandes & > Flores (agua y etanol); Nostro et al. (2005) & \\
\hline Tilia tomentosa & Tilo plateado & > Flores (metanol 70\%); Stamatis et al. (2003) & \\
\hline \multicolumn{4}{|l|}{ Trichocolaceae } \\
\hline Trichocolea lanata & - & & $\begin{array}{l}\text { Ácido cinámico; } \\
\text { Epifano et al. (2006) }\end{array}$ \\
\hline \multicolumn{4}{|l|}{ Urticaceae } \\
\hline Pouzolzia pentandra & - & A Hoja (metanol); Bhamaraprevati et al. (2003) & \\
\hline \multicolumn{4}{|l|}{ Verbenaceae } \\
\hline Lippia citriodora & Cedrón & > Hojas (metanol 70\%); Stamatis et al. (2003) & $\begin{array}{l}\text { Aceite esencial; } \\
\text { Bergonzelli et al. (2003); } \\
\text { Ohno et al. (2003) }\end{array}$ \\
\hline Phyla nodiflora & Falso tymo & $\begin{array}{l}\text { Planta completa (etanol); Wang y } \\
\text { Huang (2005a) }\end{array}$ & \\
\hline Vitex rotundifolia & Kolokolo & A Fruto; Bae et al. (1998) & \\
\hline \multicolumn{4}{|l|}{ Violaceae } \\
\hline Viola mandshurica & Sumire & $\begin{array}{l}\text { Planta completa (etanol); Wang y } \\
\text { Huang (2005a) }\end{array}$ & \\
\hline \multicolumn{4}{|l|}{ Vitaceae } \\
\hline Cayratia japonica & Arbusto mortal & $\begin{array}{l}\text { Planta completa (etanol); Wang y } \\
\text { Huang (2005a) }\end{array}$ & \\
\hline Vitis vinifera & Semilla de uva & & $\begin{array}{l}\text { Protocianidinas; } \\
\text { Funatogawa et al. (2004) }\end{array}$ \\
\hline Alpinia speciosa & Planta de concha & A Raíz (etanol); Wang y Huang (2005a) & \\
\hline \multicolumn{4}{|l|}{ Zingiberaceae } \\
\hline Amomum villosum • & - & A Fruto (etanol); Li et al. (2005) & \\
\hline Amomum xanthioides & - & > Semilla (agua); Bae et al. (1998) & \\
\hline Curcuma longa $\bullet$ & Azafrán & 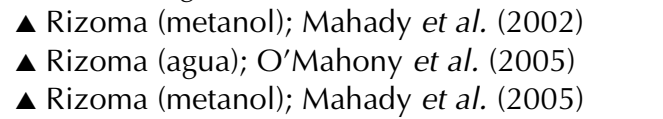 & $\begin{array}{l}\text { Polifenol; Mahady } \\
\text { et al. (2002) }\end{array}$ \\
\hline Elettaria cardamomum & Cardamomo & $\begin{array}{l}\text { Semilla (etanol); Imai et al. (2001), } \\
\text { Nostro et al. (2005) } \\
\text { ه Semillas (metanol); Mahady et al. (2005) }\end{array}$ & \\
\hline Kaempferia galanga & Galanga & $\begin{array}{l}\text { A Rizoma (metanol); Bhamaraprevati } \\
\text { et al. (2003) }\end{array}$ & \\
\hline Larrea divaricata & Jarilla & $\begin{array}{l}\text { Hoja y ramas blandas (agua); Stege } \\
\text { et al. (2006) }\end{array}$ & \\
\hline Zingiber officinale $\bullet$ & Gengibre & 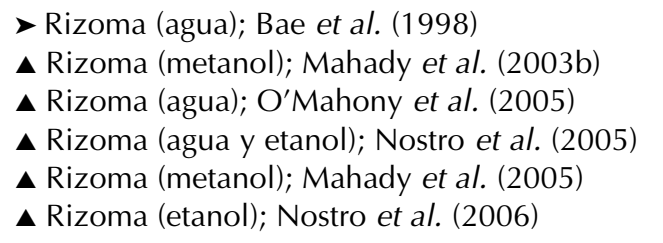 & $\begin{array}{l}\text { Polifenol; Mahady } \\
\text { et al. (2003b) }\end{array}$ \\
\hline
\end{tabular}

